\title{
Comparison of computationally cheap methods for providing insight into the crystal packing of highly bromomethylated azobenzenes
}

\author{
Christophe M. L. Vande Velde, Matthias Zeller and Vladimir A. Azov
}

Acta Cryst. (2018). C74, 1692-1702

\begin{tabular}{|l|}
\hline IUCr Journals \\
CRYSTALLOGRAPHY JOURNALS ONLINE \\
Copyright C International Union of Crystallography \\
Author(s) of this paper may load this reprint on their own web site or institutional repository provided that \\
this cover page is retained. Republication of this article or its storage in electronic databases other than as \\
specified above is not permitted without prior permission in writing from the IUCr. \\
For further information see http://journals.iucr.org/services/authorrights.html
\end{tabular}




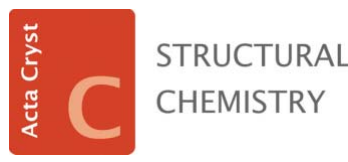

ISSN 2053-2296

Received 2 August 2018

Accepted 29 October 2018

Edited by A. R. Kennedy, University of Strathclyde, Scotland

${ }^{1}$ This paper is dedicated to the memory of Professor Philip Coppens, a true giant in crystallography, and an inspiration.

Keywords: CLP calculations; Hirshfeld surface analysis; enrichment ratio; crystal structure; CrystalExplorer; azobenzene; crystal packing; halogen bonding.

CCDC references: 1876016; 1876015; $1876014 ; 1876013 ; 1876012$

Supporting information: this article has supporting information at journals.iucr.org/c

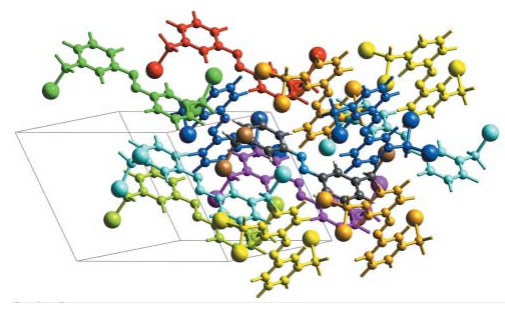

(C) 2018 International Union of Crystallography

\section{Comparison of computationally cheap methods for providing insight into the crystal packing of highly bromomethylated azobenzenes ${ }^{1}$}

\author{
Christophe M. L. Vande Velde, ${ }^{\mathrm{a} *}$ Matthias Zeller $^{\mathrm{b}}$ and Vladimir A. Azov ${ }^{\mathrm{c} *}$ \\ ${ }^{\mathbf{a}}$ Faculty of Applied Engineering, Advanced Reactor Technology, University of Antwerp, Groenenborgerlaan 171, \\ Antwerpen 2020, Belgium, 'bepartment of Chemistry, Purdue University, West Lafayette, IN 47907, USA, and \\ ${ }^{\mathbf{c}}$ Department of Chemistry, University of the Free State, PO Box 339, Bloemfontein, Free State, 9300, South Africa. \\ *Correspondence e-mail: christophe.vandevelde@uantwerpen.be, azovv@ufs.ac.za
}

For five bromomethylated azobenzenes, namely $(E)$-[4-(bromomethyl)phenyl][4-(dibromomethyl)phenyl]diazene, $\mathrm{C}_{14} \mathrm{H}_{11} \mathrm{Br}_{3} \mathrm{~N}_{2},(E)$-1,2-bis[4-(dibromomethyl)phenyl]diazene, $\mathrm{C}_{14} \mathrm{H}_{10} \mathrm{Br}_{4} \mathrm{~N}_{2}$, (E)-[3-(bromomethyl)phenyl][3-(dibromomethyl)phenyl]diazene, $\mathrm{C}_{14} \mathrm{H}_{11} \mathrm{Br}_{3} \mathrm{~N}_{2}$, (E)-[3-(dibromomethyl)phenyl][3-(tribromomethyl)phenyl]diazene, $\mathrm{C}_{14} \mathrm{H}_{10} \mathrm{Br}_{4} \mathrm{~N}_{2}$, and (E)-1,2-bis[3-(dibromomethyl)phenyl]diazene, $\mathrm{C}_{14} \mathrm{H}_{9} \mathrm{Br}_{5} \mathrm{~N}_{2}$, the computationally cheap CLP PIXEL approach and CrystalExplorer were used for calculating lattice energies and performing Hirshfeld surface analysis via the enrichment ratios of atomic contacts. The procedures and caveats are discussed in detail. The findings from these tools are contrasted with the results of geometric analysis of the structures. We conclude that an energy-based discussion of the crystal packing provides substantially more insight than one based purely on geometry, as has so long been the custom in crystallography. In addition, we find a surprising shortage of halogen-halogen interactions in these highly bromomethylated compounds.

\section{Introduction}

In this article, we look at five different azobenzene derivatives (Merino, 2011), all bromomethylated to various degrees. We will discuss the geometry of the crystals in terms of distances and angles, but also in terms of CLP PIXEL (Gavezzotti, 2008, 2011) and CrystalExplorer (CE; McKinnon et al., 2004) calculations, as well as Hirshfeld plots and the enrichment ratios resulting from them, and compare between these various instruments at the fingertips of today's crystallographers. We will compare the values for the lattice energies that result from CE and CLP-PIXEL, and, for good measure, include numbers from the UNI force field as implemented in CLP and Mercury (Macrae et al., 2008). In terms of crystal packing, one would expect to find plenty of halogen-halogen interactions and halogen bonds (Metrangolo et al., 2008; Desiraju \& Parthasarathy, 1989) in these compounds, and their significance to the structures will also be discussed.

Analysis of the X-ray structures of derivatives 3 and $\mathbf{4}$ (see Fig. 1) gave evidence of a dynamic disorder due to a pedalling motion (Harada \& Ogawa, 2009) of the central $\mathrm{N}=\mathrm{N}$ double bond. Using variable-temperature X-ray and van 't Hoff plots it was possible to determine the thermodynamic parameters for the pedal motion (Vande Velde et al., 2015). Computational methods were employed to look into the differences in the temperature-dependent behaviour of the dynamic disorder of these two compounds.

With these findings, we became motivated to perform an $\mathrm{X}$-ray study of the whole family of similar brominated azo- 
benzene derivatives to get insight into their packing modes and stabilizing intermolecular interactions in the crystalline state. Compounds 5, 6 and $\mathbf{7}$ (see Fig. 1) have been isolated as the by-products of the bromination reactions. To make the series of compounds more extensive, we prepared additional derivatives of $\mathbf{2}$ by bromination of $\mathbf{7}$, which afforded compounds 8 and 9 (Fig. 1). All new brominated azobenzenes easily afforded X-ray-quality crystals that showed rather different packing motifs. We used their crystal structures as benchmarks for in-depth testing of various crystal structure analysis tools.

\section{Experimental}

\subsection{Synthesis and crystallization}

The brominated azobenzene derivatives were prepared by radical bromination of $(E)$-1,2-bis(4-methylphenyl)diazene, $\mathbf{1}$, and (E)-1,2-bis(3-methylphenyl)diazene, 2, using $N$-bromosuccinimide (NBS)/benzoyl peroxide (BPO) (Fig. 1) according to a literature procedure (Jousselme et al., 2003). Our target products were the symmetric dibrominated derivatives $\mathbf{3}$ and 4, which were later employed for the preparation of functional TTF-AB macrocycles (Azov et al., 2014). Along with 3 and 4, the polybrominated derivatives 5 and $\mathbf{6}$ could be separated from the reaction of $\mathbf{1}$, whereas tribrominated derivative $\mathbf{7}$ was separated from the bromination of $\mathbf{2}$. All compounds could be easily crystallized, affording X-ray-quality crystals.

2.1.1. (E)-1,2-Bis[4-(bromomethyl)phenyl]diazene (2), (E)[4-(dibromomethyl)phenyl][4-(bromomethyl)phenyl]diazene (5) and (E)-1,2-bis[4-(dibromomethyl)phenyl]diazene (6). To compound $1(1.0 \mathrm{~g}, 4.8 \mathrm{mmol})$ in dry $\mathrm{CCl}_{4}(40 \mathrm{ml})$ were added NBS (2.05 g, $11.5 \mathrm{mmol}, 2.4$ equiv.) and BPO (47 mg, $0.18 \mathrm{mmol}$ ). The reaction mixture was stirred for $2.5 \mathrm{~h}$ under reflux and the mixture was then hot-filtered. The filtrate was washed with $\mathrm{CCl}_{4}(10 \mathrm{ml})$. The organic phase was washed with warm water and dried $\left(\mathrm{Na}_{2} \mathrm{SO}_{4}\right)$. The residue was recrystallized from butanone and $\mathrm{MeOH}$ to afford $0.81 \mathrm{~g}$ of $\mathbf{3}$. The butanone mother liquor was evaporated to dryness and then chromatographed on silica $\left[\mathrm{CH}_{2} \mathrm{Cl}_{2}\right.$ /petroleum ether (PE), 1:1 $v / v$ ] to give an additional $60 \mathrm{mg}$ of $\mathbf{3}$ (total yield: $0.87 \mathrm{~g}$, $2.36 \mathrm{mmol}, 49 \%$ ), as well as traces of compounds 5 (yield: $38 \mathrm{mg}, 0.085 \mathrm{mmol}, 1.8 \%$ ) and 6 (yield: $18 \mathrm{mg}, 0.034 \mathrm{mmol}$, $0.7 \%$ ). Compound $\mathbf{3}$ has been characterized and reported before (Azov et al., 2014; Jousselme et al., 2003). Compound 5 was recrystallized by slow diffusion of hexane into a chloroform solution, affording orange crystals (m.p. $146-148{ }^{\circ} \mathrm{C}$ ). $R_{\mathrm{F}}=0.41\left(\mathrm{CH}_{2} \mathrm{Cl}_{2} /\right.$ cyclohexane, $\left.1: 2 v / v\right) .{ }^{1} \mathrm{H} \mathrm{NMR}\left(\mathrm{CDCl}_{3}\right.$, $200 \mathrm{MHz}): \delta 4.56(s, 2 \mathrm{H}), 6.71(s, 1 \mathrm{H}), 7.52-758(m, 2 \mathrm{H}), 7.69-$ $7.74(m, 2 \mathrm{H}), 7.88-7.95(m, 4 \mathrm{H}) .{ }^{13} \mathrm{C} \mathrm{NMR}\left(\mathrm{CDCl}_{3}, 50 \mathrm{MHz}\right): \delta$ 32.6, 40.0, 123.1, 123.4, 127.5, 129.9, 141.0, 144.2, 152.1, 152.9. MS (EI, $70 \mathrm{eV}) \mathrm{m} / \mathrm{z}(\mathrm{I} \%): 444$ (15) $\left[\mathrm{M}^{+}\right], 365$ (100), 286 (40), 169 (15), 168 (15). Compound 6 was recrystallized by slow diffusion of hexane into a chloroform solution, affording long (up to $10 \mathrm{~mm}$ ) rod-shaped red-orange crystals (m.p. 151$\left.153{ }^{\circ} \mathrm{C}\right) . R_{\mathrm{F}}=0.45\left(\mathrm{CH}_{2} \mathrm{Cl}_{2} /\right.$ cyclohexane, $\left.1: 2 v / v\right) .{ }^{1} \mathrm{H}$ NMR $\left(\mathrm{CDCl}_{3}\right): \delta 6.71(s, 2 \mathrm{H}), 7.70-7.76(m, 4 \mathrm{H}), 7.89-7.96(m, 4 \mathrm{H})$. ${ }^{13} \mathrm{C} \mathrm{NMR}\left(\mathrm{CDCl}_{3}\right): \delta 39.3,123.2,127.5,144.4,152.8$. MS (EI, $70 \mathrm{eV}) \mathrm{m} / z$ (I\%): 522 (20) $\left[M^{+}\right], 443$ (100), 364 (100), 285 (20), $168(30)$.

2.1.2. (E)-1,2-Bis[3-(bromomethyl)phenyl]diazene (4) and (E)-[3-(dibromomethyl)phenyl][3-(bromomethyl)phenyl]diazene (7). To compound $2(1.8 \mathrm{~g}, 8.57 \mathrm{mmol})$ in dry $\mathrm{CCl}_{4}$ $(60 \mathrm{ml})$ were added NBS (4.27 g, $24 \mathrm{mmol}, 2.8$ equiv.) and BPO $(75 \mathrm{mg}, 0.31 \mathrm{mmol})$. The reaction mixture was stirred for $6 \mathrm{~h}$ under reflux and the mixture was then hot-filtered. The filtrate was washed with $\mathrm{CCl}_{4}(15 \mathrm{ml})$. The organic phase was washed with warm water and dried $\left(\mathrm{Na}_{2} \mathrm{SO}_{4}\right)$. The crude<smiles>Cc1ccc(N=Nc2ccc(C(Br)c3ccc(N=Nc4ccc(CBr)cc4)cc3)cc2)cc1</smiles>

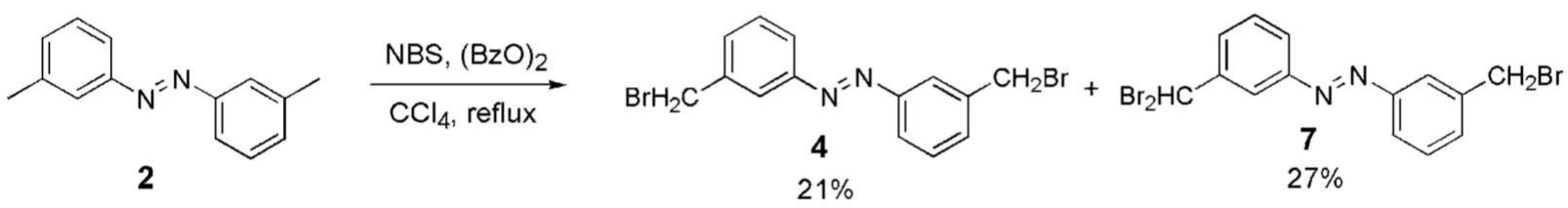<smiles>CC(C)(C)c1cccc(N=Nc2cccc(C(Br)Br)c2)c1</smiles>

Figure 1

Synthesis of the polybromomethylated azobenzene derivatives 1-9. 
Table 1

Experimental details.

All determinations were carried out at $100 \mathrm{~K}$ on a Bruker SMART 1000 diffractometer. The absorption correction was multi-scan, using SADABS (Krause et al., 2015) for 5-8 and TWINABS (Sheldrick, 2012) for $\mathbf{9}$. H-atom parameters were constrained.

\begin{tabular}{|c|c|c|c|}
\hline & 5 & 6 & 7 \\
\hline \multicolumn{4}{|l|}{ Crystal data } \\
\hline Chemical formula & $\mathrm{C}_{14} \mathrm{H}_{11} \mathrm{Br}_{3} \mathrm{~N}_{2}$ & $\mathrm{C}_{14} \mathrm{H}_{10} \mathrm{Br}_{4} \mathrm{~N}_{2}$ & $\mathrm{C}_{14} \mathrm{H}_{11} \mathrm{Br}_{3} \mathrm{~N}_{2}$ \\
\hline$M_{\mathrm{r}}$ & 446.98 & 525.88 & 446.98 \\
\hline Crystal system, space group & Monoclinic, $P 2_{1} / c$ & Monoclinic, $C 2 / c$ & Monoclinic, $P 2_{1} / c$ \\
\hline$a, b, c(\AA)$ & $8.538(1), 5.283(1), 32.801(4)$ & $20.379(3), 8.6401(10), 9.8451(10)$ & $\begin{array}{l}9.1219(12), 16.904(2), \\
\quad 10.3633(14)\end{array}$ \\
\hline$\alpha, \beta, \gamma\left(^{\circ}\right)$ & 90, $99.692(5), 90$ & $90,114.797(2), 90$ & $90,112.122(2), 90$ \\
\hline$V\left(\AA^{3}\right)$ & $1458.4(4)$ & $1573.7(3)$ & $1480.4(3)$ \\
\hline$Z$ & 4 & 4 & 4 \\
\hline Radiation type & Мо $K \alpha$ & Мо $K \alpha$ & Мо $K \alpha$ \\
\hline$\mu\left(\mathrm{mm}^{-1}\right)$ & 8.29 & 10.22 & 8.16 \\
\hline Crystal size $(\mathrm{mm})$ & $0.45 \times 0.35 \times 0.18$ & $0.51 \times 0.48 \times 0.38$ & $0.52 \times 0.45 \times 0.15$ \\
\hline \multicolumn{4}{|l|}{ Data collection } \\
\hline$T_{\min }, T_{\max }$ & $0.316,0.746$ & $0.406,0.746$ & $0.349,0.746$ \\
\hline $\begin{array}{l}\text { No. of measured, independent and } \\
\text { observed }[I>2 \sigma(I)] \text { reflections }\end{array}$ & $13694,4445,3947$ & $5663,2322,2049$ & $12573,4362,3587$ \\
\hline$R_{\text {int }}$ & 0.040 & 0.028 & 0.038 \\
\hline$(\sin \theta / \lambda)_{\max }\left(\AA^{-1}\right)$ & 0.732 & 0.730 & 0.729 \\
\hline \multicolumn{4}{|l|}{ Refinement } \\
\hline$R\left[F^{2}>2 \sigma\left(F^{2}\right)\right], w R\left(F^{2}\right), S$ & $0.039,0.088,1.15$ & $0.024,0.056,1.02$ & $0.041,0.104,1.03$ \\
\hline No. of reflections & 4445 & 2322 & 4362 \\
\hline No. of parameters & 172 & 92 & 172 \\
\hline$\Delta \rho_{\max }, \Delta \rho_{\min }\left(\mathrm{e} \AA^{-3}\right)$ & $1.41,-1.06$ & $0.82,-0.60$ & $2.24,-1.56$ \\
\hline
\end{tabular}

$8 \quad 9$

Crystal data

Chemical formula

$M_{\mathrm{r}}$

Crystal system, space group

$a, b, c(\AA)$

$\alpha, \beta, \gamma\left({ }^{\circ}\right)$

$V\left(\AA^{3}\right)$

$Z$

Radiation type

$\mu\left(\mathrm{mm}^{-1}\right)$

Crystal size (mm)

Data collection

$T_{\min }, T_{\max }$

No. of measured, independent and observed

$[I>2 \sigma(I)]$ reflections

$R_{\text {int }}$

$(\sin \theta / \lambda)_{\max }\left(\AA^{-1}\right)$

$\mathrm{C}_{14} \mathrm{H}_{10} \mathrm{Br}_{4} \mathrm{~N}_{2}$
525.88
Triclinic, $P \overline{1}$
$4.899(2), 8.294(2), 9.942(3)$
$98.103(4), 103.640(3), 96.650(3)$
$384.0(2)$
1
Mo $K \alpha$
10.47
$0.45 \times 0.25 \times 0.20$

$0.308,0.746$
$5417,2249,1993$
0.042
0.729

$0.033,0.085,1.05$
2249
92
0
$1.08,-1.11$

$\Delta \rho_{\max }, \Delta \rho_{\min }\left(\mathrm{e} \AA^{-3}\right)$
$\mathrm{C}_{14} \mathrm{H}_{9} \mathrm{Br}_{5} \mathrm{~N}_{2}$

604.78

Triclinic, $P \overline{1}$

7.0161 (11), 8.5634 (13), 14.897 (2) 103.257 (2), 102.974 (2), 91.703 (2) $845.8(2)$

Mo $K \alpha$

11.87

$0.45 \times 0.43 \times 0.21$

$0.014,0.052$

$15148,8987,6827$

0.066

0.731

$0.051,0.137,0.99$

8987

213

$1.81,-1.56$

Computer programs: APEX2 (Bruker, 2009), SAINT (Bruker, 2009), SHELXS2013 (Sheldrick, 2008b), SHELXL2018 (Sheldrick, 2015), shelXle (Hübschle et al., 2011) and SHELXL2018 (Sheldrick, 2015).

mixture was separated by two consecutive chromatographies on silica $\left(\mathrm{CH}_{2} \mathrm{Cl}_{2} / \mathrm{PE}, 1: 1 v / v\right.$, then toluene/PE, 2:3 $\left.v / v\right)$, with separations being complicated by the similar $R_{\mathrm{F}}$ values of the products. Recrystallization from $\mathrm{MeCN}$ afforded $0.66 \mathrm{~g}$ (1.79 mmol, $21 \%)$ of analytically pure 4 that has been reported previously (Azov et al., 2014; Jousselme et al., 2003). Additionally, $1.05 \mathrm{~g}(2.35 \mathrm{mmol}, 27 \%)$ of tribromide 7 was obtained as an orange crystalline solid. X-ray-quality crystals were grown by slow diffusion of hexane into a chloroform solution (m.p. $\left.120-121^{\circ} \mathrm{C}\right) . R_{\mathrm{F}}=0.45\left(\mathrm{CH}_{2} \mathrm{Cl}_{2} /\right.$ cyclohexane, $1: 2 v / v) .{ }^{1} \mathrm{H}$ NMR $\left(\mathrm{CDCl}_{3}, 200 \mathrm{MHz}\right): \delta 4.59(s, 2 \mathrm{H}), 6.74(s$, 1H), 7.48-7.59 (m, 2H), 7.70-7.74 ( $m, 2 \mathrm{H}), 7.86-7.97(m, 2 \mathrm{H})$, 8.10-8.12 $(\mathrm{m}, 2 \mathrm{H}) .{ }^{13} \mathrm{C} \mathrm{NMR}\left(\mathrm{CDCl}_{3}, 50 \mathrm{MHz}\right): \delta 32.7,40.1$, 120.5, 123.0, 123.5, 124.6, 129.1, $129.6(\times), 131.8,139.0,143.0$, 152.2, 152.6. MS (EI, $70 \mathrm{eV}) \mathrm{m} / z$ (I\%): $444(80)\left[M^{+}\right], 365$ (50), 275 (40), 247 (60), 197 (60), 169 (100). 
2.1.3. (E)-1,2-Bis[3-(dibromomethyl)phenyl]diazene (8) and $(\boldsymbol{E})$-[3-(tribromomethyl)phenyl][3-(dibromomethyl)phenyl]diazene (9). To compound 7 (0.95 g, $2.13 \mathrm{mmol})$ in dry $\mathrm{CCl}_{4}$ $(30 \mathrm{ml})$ were added NBS ( $0.76 \mathrm{~g}, 4.3 \mathrm{mmol}, 2$ equiv.) and BPO $(31 \mathrm{mg})$. The reaction mixture was stirred for $2 \mathrm{~h}$ under reflux and the mixture was then hot-filtered. The filtrate was washed with $\mathrm{CCl}_{4}(10 \mathrm{ml})$. The organic phase was washed with warm water and dried $\left(\mathrm{Na}_{2} \mathrm{SO}_{4}\right)$. The crude mixture was separated by chromatography on silica (toluene/PE, 2:3 v/v) to afford $0.43 \mathrm{~g}(0.817 \mathrm{mmol}, 38 \%)$ of 8 and $0.15 \mathrm{~g}(0.248 \mathrm{mmol}, 12 \%)$ of 9, both orange crystalline solids. X-ray-quality crystals of tetrabromide $\mathbf{8}$ were grown by slow diffusion of hexane into a chloroform solution (m.p. $\left.142-143^{\circ} \mathrm{C}\right) . R_{\mathrm{F}}=0.50\left(\mathrm{CH}_{2} \mathrm{Cl}_{2} /\right.$ cyclohexane, $1: 2 v / v) .{ }^{1} \mathrm{H}$ NMR $\left(\mathrm{CDCl}_{3}, 200 \mathrm{MHz}\right): \delta 6.75(s$, $2 \mathrm{H}), 7.52-7.60(m, 2 \mathrm{H}), 7.71-7.77(m, 2 \mathrm{H}), 7.89-7.95(m, 2 \mathrm{H})$, 8.12-8.14 (m, 2H). ${ }^{13} \mathrm{C} \mathrm{NMR}\left(\mathrm{CDCl}_{3}, 50 \mathrm{MHz}\right): \delta 40.0,120.6$, 124.7, 129.3, 129.6, 143.0, 152.1. MS (EI, $70 \mathrm{eV}) \mathrm{m} / \mathrm{z}(\mathrm{I} \%)$ : $522(80)\left[M^{+}\right], 443$ (60), 275 (70), 247 (100), 168 (30). X-rayquality crystals of pentabromide 9 were grown by slow diffusion of hexane into a chloroform solution (m.p. $130-132{ }^{\circ} \mathrm{C}$ ). $R_{\mathrm{F}}=0.57\left(\mathrm{CH}_{2} \mathrm{Cl}_{2} /\right.$ cyclohexane, $\left.1: 2 v / v\right) .{ }^{1} \mathrm{H}$ NMR $\left(\mathrm{CDCl}_{3}\right.$, $200 \mathrm{MHz}): \delta 6.75(s, 1 \mathrm{H}), 7.53-7.62(m, 2 \mathrm{H}), 7.73-7.77(m, 1 \mathrm{H})$, 7.90-7.96 $(m, 2 \mathrm{H}), 8.14-8.18(m, 2 \mathrm{H}), 8.58-8.60(m, 1 \mathrm{H}) .{ }^{13} \mathrm{C}$ NMR $\left(\mathrm{CDCl}_{3}, 50 \mathrm{MHz}\right): \delta 34.8,40.0,120.6,121.5,124.0,124.7$, 129.0, 129.1, 129.4, 129.7, 143.1, 148.1, 151.6, 152.1. MS (EI, $70 \mathrm{eV}) \mathrm{m} / \mathrm{z}$ (I\%): $600(40)\left[M^{+}\right], 521$ (100), 353 (20), 325 (30), 275 (40), 247 (70), 168 (20), 167 (20).

\subsection{X-ray crystallography}

Crystal data, data collection and structure refinement details are summarized in Table 1 . Structure 9 was found to be nonmerohedrally twinned. The orientation matrices for the two components were identified using the program CELL_ NOW (Sheldrick, 2008a), with the two components being related by a $180^{\circ}$ rotation around the real $a$ axis. The two components were integrated using SAINT (Bruker, 2010) and corrected for absorption using TWINABS (Sheldrick, 2012). The structure was solved using direct methods with only the non-overlapping reflections of component 1 . The structure was refined using the HKLF 5 routine with all reflections of both components (including the overlapping ones), resulting in a fraction of 0.481 (1) for the second component.

If disorder was evident from the difference maps, various models were tried for the best fit. Often the disorder populations were sufficiently low that the original model still yielded the best fit. For structure 9, minor but clearly resolved disorder was observed for the dibromomethyl group. The major and minor moieties were restrained to have similar geometries (SAME restraint of SHELXL, with an s.u. value of $0.02 \AA^{2}$ ). Atom $\mathrm{C} 10$ was included in the disorder modeling and 1,2 and $1,3 \mathrm{C}-\mathrm{C}$ distances involving the major and minor components of $\mathrm{C} 10$ were restrained to be similar (SADI restraint of SHELXL, with an s.u. value of $0.02 \AA$ ). $U^{i j}$ components of the anisotropic displacement parameters for disordered atoms closer to each other than $2.0 \AA$ were restrained to be similar (SIMU restraint of $S H E L X L$ ). Subject to these conditions, the occupancy ratio refined to 0.9601 (19):0.0399 (19).

All $\mathrm{H}$ atoms were modelled in riding mode. $\mathrm{C}-\mathrm{H}$ distances were $0.95,1.00$ and $0.99 \AA$ for $s p^{2} \mathrm{CH}, s p^{3} \mathrm{CH}$ and $\mathrm{CH}_{2}$ groups, respectively. In all cases, $U_{\text {iso }}(\mathrm{H})$ values were set at $1.2 U_{\text {eq }}(\mathrm{C})$.

Displacement ellipsoid plots of all structures can also be found in the supporting information as Figs. S11-S15.

\subsection{Calculations}

CLP PIXEL calculations (Gavezzotti, 2008, 2011) were based on electron-density cubes calculated with GAUSSIAN09 (Frisch et al., 2016) from B3LYP/6-311(d,p) and MP2/ 6-311(d,p) wavefunctions of the various molecules at the fixed geometries from the crystals, with carbon-hydrogen distances renormalized to neutron values $(1.083 \AA$ ) . CLP results for the MP2 6-311G(d,p) densities are consistently about $3 \mathrm{~kJ} \mathrm{~mol}^{-1}$ in energy above the results based on B3LYP 6-311G(d,p) densities, and are reproduced in full in Table $\mathrm{S} 1$ in the supporting information, with a summary in Table 2. Standard CLP parameters were used, where a cluster was built up to a distance of $40 \AA$ between molecular centres of mass.

CE lattice energies were calculated with CrystalExplorer 17 (McKinnon et al., 2004; Turner et al., 2017). A B3LYP/6$311 \mathrm{G}(\mathrm{d}, \mathrm{p})$ wavefunction was calculated for a single molecule with the TONTO quantum chemical program (Jayatilaka \& Grimwood, 2003), and intermolecular energies were then calculated according to the $\mathrm{CE}$ algorithm. It should be noted that the scale factors used for the various terms in the expression for the lattice energy have been optimized for the 6-31G $(\mathrm{d}, \mathrm{p})$ basis set (which in its standard form does not include Br) (Thomas et al., 2018), but we expect the differences with respect to $6-311 \mathrm{G}(\mathrm{d}, \mathrm{p})$ to be minimal. Clusters were formed with molecules within a distance of $10 \AA$ from the Hirshfeld surface (McKinnon et al., 2004, 1998; Spackman \& McKinnon, 2002) of the central molecule, and all fragments found within this distance were completed to full molecules. Convergence of the calculated lattice energies was only reached with clusters of this size (see Fig. 2). It should be noted that the output of $\mathrm{CE}$ features the total interaction energy of the cluster with the central entity, which, when the cluster is centred around one molecule, needs to be halved to arrive at a number per mole for the lattice energy.

Fingerprint $d_{\mathrm{i}}-d_{\mathrm{e}}$ plots (Spackman \& McKinnon, 2002) were generated in CE from the calculated Hirshfeld surfaces, and the percentage populations divided over the various atomic species were recorded. These percentages were then used in a spreadsheet for calculating enrichment ratios as defined by Jelsch and co-authors (Jelsch et al., 2014).

\section{Results and discussion}

\subsection{Structures}

3.1.1. Compound 5. Compound 5 contains only three $\mathrm{Br}$ atoms. It crystallizes in the space group $P 2_{1} / c$, with one molecule in the asymmetric unit, and packs in a herringbone pattern (Fig. 3). 


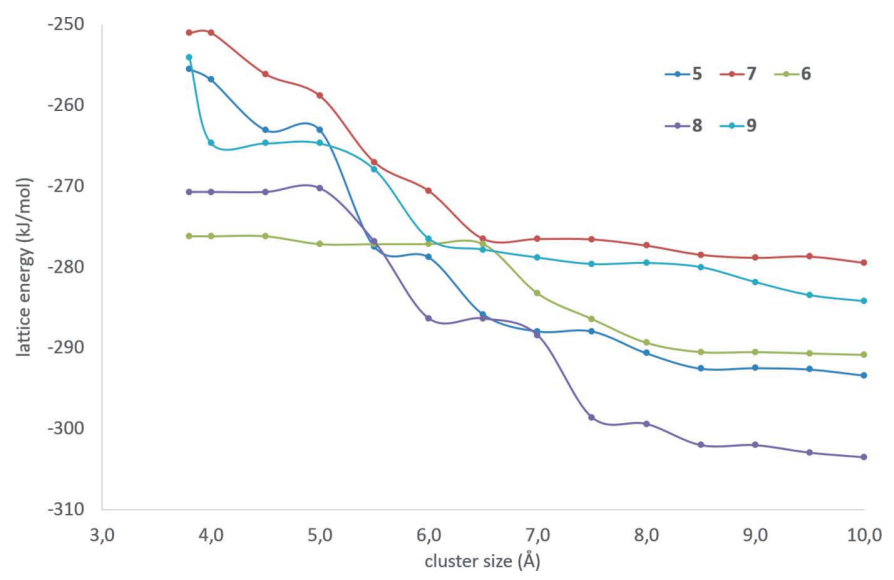

Figure 2

Energy dependence on cluster size for $\mathrm{CE}$ energies for the five brominated azobenzenes 5-9.

Contacts are listed in Table S2 in the supporting information. There is an $\mathrm{H} \cdots \mathrm{Br}$ contact within the columns from the $\mathrm{CHBr}_{2} \mathrm{H}$ atom to one of the $\mathrm{Br}$ atoms of the translated molecule along the $c$ axis (Fig. 3, E), and of the same $\mathrm{H}$ atom to the $\mathrm{Br}$ atom of the $\mathrm{CH}_{2} \mathrm{Br}$ group in the next column (Fig. 3, D). The same molecules are in close contact through a $\mathrm{Br} \cdots \mathrm{Br}$ interaction (Fig. 3, C). The $\mathrm{Br}$ atom in the $\mathrm{CHBr}_{2}$ group that is not involved in these contacts instead interacts with one of the $\mathrm{H}$ atoms in the $\mathrm{CH}_{2} \mathrm{Br}$ group in the next column (Fig. 3, A), as well as with the $\mathrm{Br}$ atom in the same group (Fig. 3, B), and with its own symmetry-equivalent through inversion symmetry in the next layer (Fig. 3, F). Due to the tilt of the columns, $\pi-\pi$ interactions are strongly tilted or laterally displaced over a large distance, but this allows $\mathrm{C}-\mathrm{H} \cdots \pi$ interactions to occur in a herringbone pattern.

From the Hirshfeld surfaces and the resulting fingerprint plots (see Figs. S6-S10 in the supporting information) calculated in CE, we can then calculate enrichment ratios (Jelsch et al., 2014), i.e. the actual contact percentage for every individual kind of atom pairs compared to the expected percentage
Table 2

Lattice energies $\left(\mathrm{kJ} \mathrm{mol}^{-1}\right)$ resulting from the various calculations for compounds 5-9.

\begin{tabular}{lccccc}
\hline & $\mathbf{5}$ & $\mathbf{6}$ & $\mathbf{7}$ & $\mathbf{8}$ & $\mathbf{9}$ \\
\hline Mercury-UNI & -135.9 & -157.7 & -147.0 & -165.4 & -165.4 \\
AA-CLP2015 (UNI) & -133.3 & -142.1 & -136.2 & -151.1 & -138.9 \\
CLP/PIXEL/B3LYP & -116.7 & -123.3 & -117.7 & -130.2 & -111.4 \\
CLP/PIXEL/MP2 & -113.3 & -120.1 & -114.1 & -127.3 & -107.2 \\
CE-B3LYP & -146.7 & -145.4 & -139.7 & -151.8 & -142.1 \\
Melting point $\left({ }^{\circ} \mathrm{C}\right)$ & $146-148$ & $151-153$ & $120-121$ & $142-143$ & $130-132$ \\
\hline
\end{tabular}

if these contacts were to be distributed randomly. Numbers higher than one mean that the contacts between atoms of two particular elements are more likely to occur than on the basis of random distribution, whereas numbers smaller than one indicate that the structure tends to avoid these contacts by preferring others.

The enrichment ratio tables are asymmetric, because the contact percentages for calculating the enrichment ratios can be quite different inside and outside the Hirshfeld surface. Enrichment is defined as a percentage of contacts relative to the expected contact percentage on a random distribution of all the atomic species over the Hirshfeld surface. This means the contact percentages and the enrichment for a particular pair of atom species are also dependent on the total amount of surface that these particular atomic species occupy. As an example, from the data summarized in Table 3, we see that contacts between $\mathrm{H}$ on the inside of the surface and $\mathrm{Br}$ outside occur less often than randomly expected (i.e. the sum of all $\mathrm{H}$ in a single molecule of $\mathbf{5}$ tends to preferentially contact atoms other than $\mathrm{Br}$ ), whereas $\mathrm{Br}$ on the inside of the surface has a slight tendency over the random distribution for contacting hydrogen on the outside (i.e. hydrogen-containing patches in the many surrounding molecules tend to cluster around the $\mathrm{Br}$ atoms). The reason for this is that the total amount of surface taken up by $\mathrm{H}$ atoms (46.7\%) is larger than that taken up by $\mathrm{Br}(36.3 \%)$. Hence, the same absolute contact surface between $\mathrm{Br}$ and $\mathrm{H}$ will represent a larger percentage with respect to the

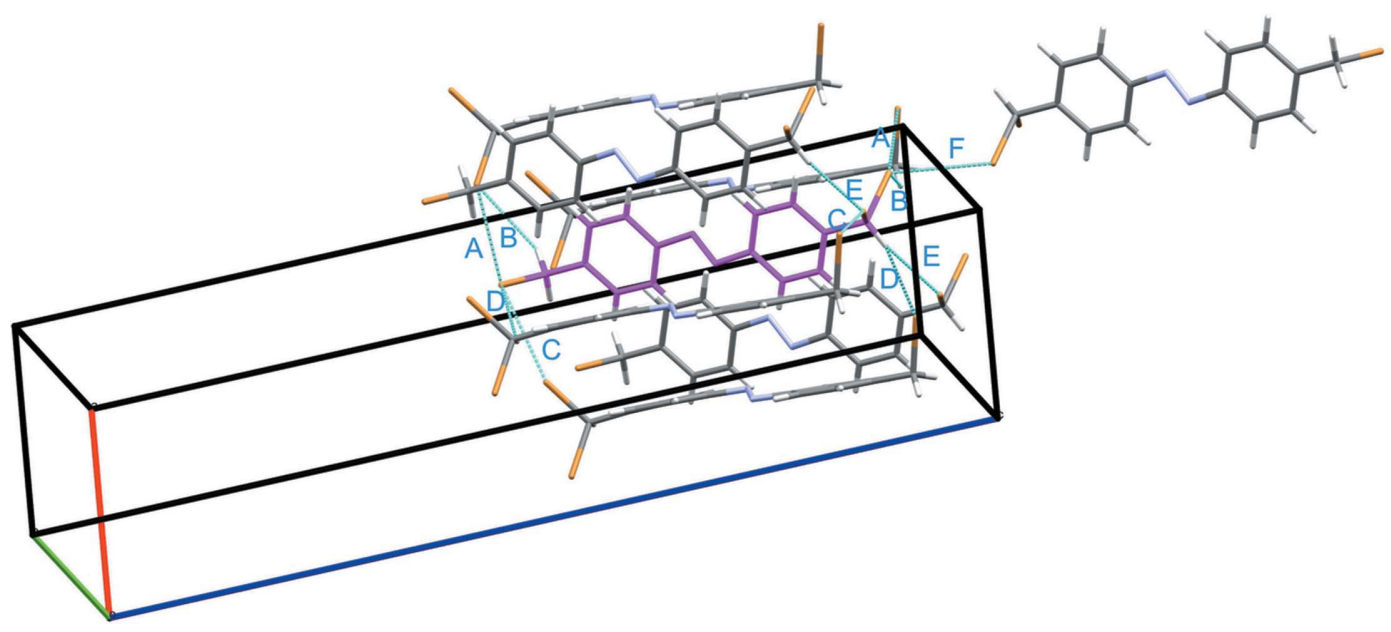

Figure 3

The crystal packing of compound 5. Contacts shorter than the van der Waals radii of the central molecule (magenta) are indicated as cyan dotted lines. The accompanying capitals refer to the contacts as specified in Table S2 of the supporting information. 
Table 3

Contact enrichment ratios in crystals of compound $\mathbf{5}$; colour coding from red to green between 0 and the maximum value in the table.

\begin{tabular}{|c|c|c|c|c|}
\hline$d_{e}$ & $\mathrm{Br}$ & $\mathrm{H}$ & $\mathrm{C}$ & $\mathrm{N}$ \\
\hline $\mathrm{Br}$ & 1.51 & 0.86 & 0 & 0 \\
\hline $\mathrm{H}$ & 1.35 & 0.68 & 1.99 & 1.90 \\
\hline $\mathrm{C}$ & 0 & 1.60 & 0 & 0 \\
\hline $\mathrm{N}$ & 0 & 1.59 & 0.15 & 0.48 \\
\hline
\end{tabular}

total $\mathrm{Br}$ surface than it will to the total $\mathrm{H}$ surface, which can lead to these apparent differences in the enrichment ratios. This is analogous to the fingerprint plot itself not being mirrorsymmetric along its diagonal.

From the enrichment ratio diagram above, we find indeed that there is no parallel packing (no enriched $\mathrm{C} \cdots \mathrm{C}, \mathrm{C} \cdots \mathrm{N}$ or $\mathrm{N} \cdot \mathrm{N}$ contacts), but instead $\mathrm{C} \cdot \mathrm{H}$ and $\mathrm{N} \cdots \mathrm{H}$ contacts have a high rate of occurrence, as well as $\mathrm{Br} \cdot \mathrm{Br}$ contacts, pointing to a herringbone packing pattern with halogen-halogen interactions between bromines, and edge-to-face ring interactions.

From an energy perspective (numbers in the text are given for the CLP/MP2/6-311G(d,p) calculations, see Table S1 for a full listing of both CE and CLP calculated energies, with a summary in Table 2), the largest interactions exist between molecules related through translation symmetry along $b$, i.e. within the column $\left(-33.3 \mathrm{~kJ} \mathrm{~mol}^{-1}\right)$. By far the largest contribution is dispersion. Interactions with molecules at $(-x$, $y+\frac{1}{2},-z+\frac{1}{2}$ ) (i.e. perpendicularly oriented molecules in neighbouring columns) give comparable numbers between -29.4 and $-32.2 \mathrm{~kJ} \mathrm{~mol}^{-1}$. Here the relative size of the dispersion contribution is smaller with respect to electrostatic and polarization contributions, pointing to a slightly larger contribution to the total of the $\mathrm{Br} \cdots \mathrm{Br}$ and $\mathrm{H} \cdots \mathrm{Br}$ contacts. The total lattice energy according to CLP/PIXEL/MP2 is $-113.3 \mathrm{~kJ} \mathrm{~mol}^{-1}$ and according to CE-B3LYP/6-311(d,p) is $-146.7 \mathrm{~kJ} \mathrm{~mol}^{-1}$.

3.1.2. Compound 6. Compound 6 crystallizes in the space group $C 2 / c$, contains four $\mathrm{Br}$ atoms per molecule and seems to be packed rather loosely, with only a few interactions apparent from the geometry. It can be described as a structure consisting of layers of tilted molecules that avoid both $\mathrm{C}-$ $\mathrm{H} \cdots \pi$ and $\pi-\pi$ contacts in this way (Fig. 4). There appear to be $\mathrm{H} \cdots \mathrm{Br}$ interactions (Fig. 4, $\mathbf{B}$ and $\mathbf{C}$ ), a $\mathrm{Br} \cdots \mathrm{N}$ interaction (Fig. 4, A) and a Br $\cdots \pi$ interaction (see Table S3 in the supporting information).

In order for the CLP program to work with half a molecule in the asymmetric unit, the corresponding symmetry-equivalent half needs to be inserted in the CIF file, and the space group adapted to $C 2$. CLP with PIXEL/MP2 calculates the sublimation enthalpy to be $-120.1 \mathrm{~kJ} \mathrm{~mol}^{-1}$ (CE $-145.4 \mathrm{~kJ} \mathrm{~mol}^{-1}$ ), with individual interactions between molecules not larger than $-22.4 \mathrm{~kJ} \mathrm{~mol}^{-1}$.

The most important contributions to the lattice energy are given in Table S1 in the supporting information. It is to be noted that dispersion interactions are again by far the greatest

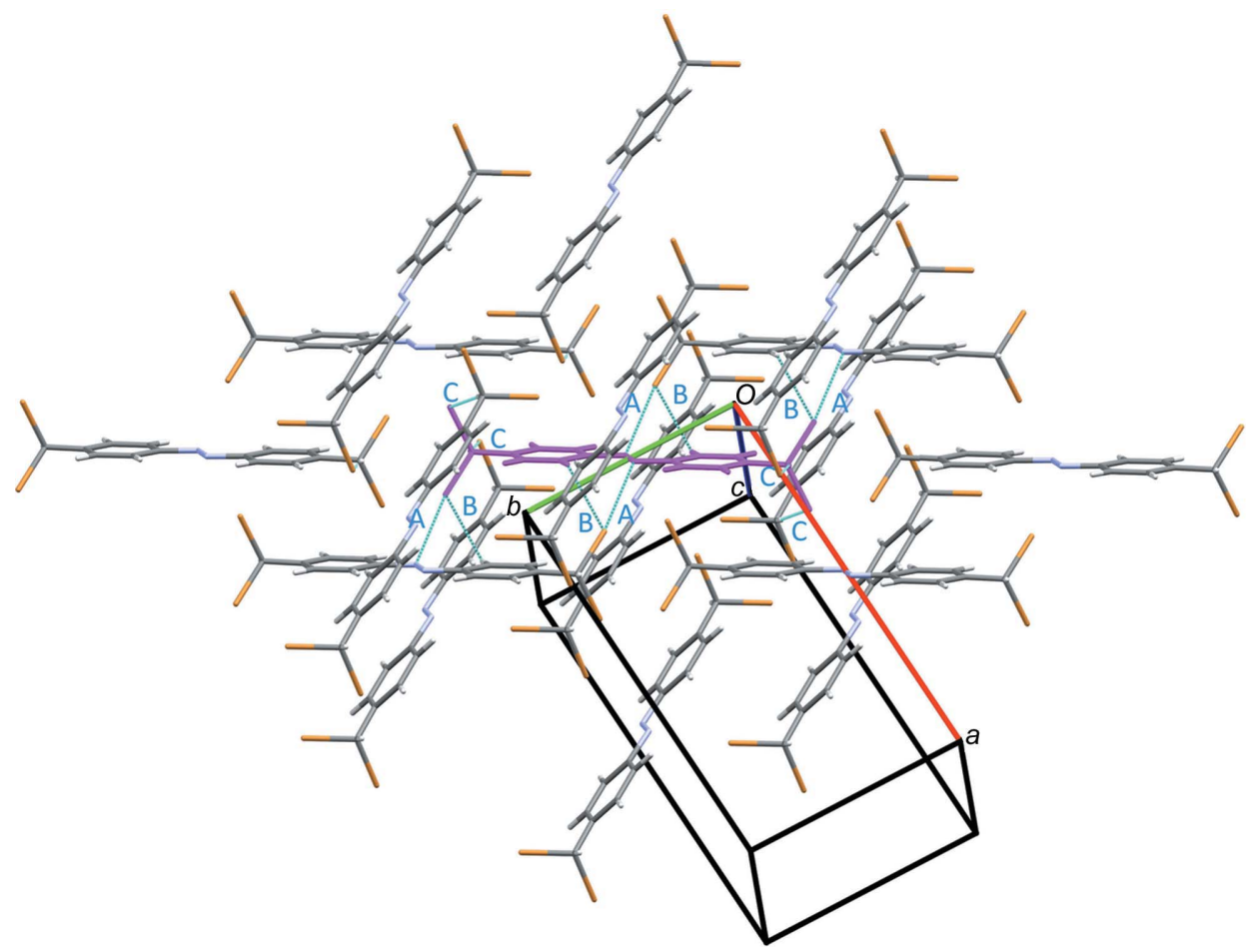

Figure 4

The crystal packing of compound 6. Contacts shorter than the van der Waals radii with the central molecule (magenta) are indicated as cyan dotted lines. The accompanying capitals refer to the contacts as specified in Table S3 of the supporting information. 
Table 4

Contact enrichment ratios in crystals of compound $\mathbf{6}$; colour coding from red to green between 0 and the maximum value in the table.

\begin{tabular}{|c|c|c|c|c|}
\hline $\mathrm{d}_{\mathrm{e}}$ & $\mathrm{Br}$ & $\mathrm{H}$ & C & $\mathrm{N}$ \\
\hline $\mathrm{Br}$ & 0.48 & 0.97 & 1.24 & 1.43 \\
\hline $\mathrm{H}$ & 1.55 & 0.82 & 0.73 & 1.10 \\
\hline C & 1.13 & 1.27 & 0.93 & 0 \\
\hline $\mathrm{N}$ & 1.23 & 1.22 & 0 & 0 \\
\hline
\end{tabular}

contributing component in all the interactions between neighbouring molecules.

The enrichment ratios given in Table 4 essentially corroborate the interactions described above, i.e. $\mathrm{H} \cdots \mathrm{Br}$ and $\mathrm{H} \cdots \mathrm{N}$ interactions, $\mathrm{Br} \cdots \mathrm{C}$ interactions and a clear lack of $\mathrm{Br} \cdots \mathrm{Br}$ halogen interactions. $\mathrm{C}$ atoms on the inside of the surface are slightly more likely to be contacted by $\mathrm{H}$ atoms and $\mathrm{Br}$ atoms, indicating a complete lack of face-to-face $\pi-\pi$ interactions. The small differences from 1 of the enrichment values in Table 4 indicate low interaction selectivity for this structure the packing appears to be based more on molecular shape and dispersion contributions than on specific interactions.

3.1.3. Compound 7. Compound 7 crystallizes in the space group $P 2_{1} / c$ and contains three $\mathrm{Br}$ atoms per molecule. It adopts an anti conformation around the double bond. The packing can be described as stacks of lengthwise-displaced
Table 5

Contact enrichment ratios in crystals of compound 7; colour coding from red to green between 0 and the maximum value in the table.

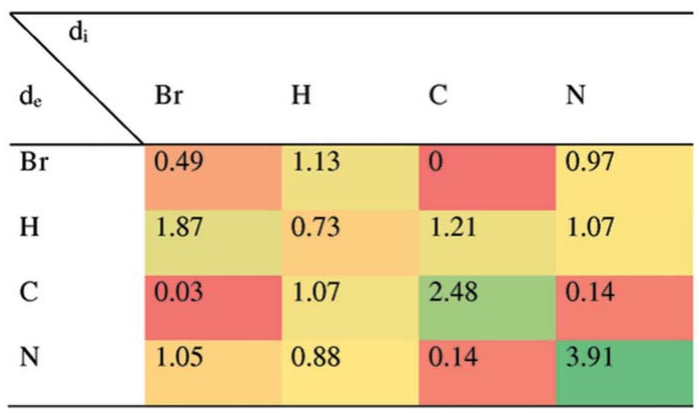

molecular parallel pairs, forming layers, with end-to-face contacts between the layers (Fig. 5).

From the geometry, one would judge that the network of interactions appears a lot stronger than in compound $\mathbf{6}$,

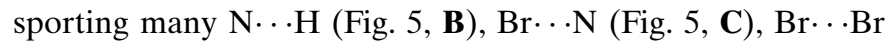
(Fig. 5, E) and $\mathrm{H} \cdots \mathrm{Br}$ (Fig. 5, $\mathbf{A}$ and $\mathbf{D}$ ) interactions, as well as a large number of ring-ring contacts. The PIXEL/MP2 calculations, however, give a sublimation enthalpy of only $-114.1 \mathrm{~kJ} \mathrm{~mol}^{-1}\left(\mathrm{CE}-139.7 \mathrm{~kJ} \mathrm{~mol}^{-1}\right)$. There is one molecular pair which has interactions that are clearly stronger than the others - the molecules that form a full-length parallel molecular pair in the packing $\left(-31.2 \mathrm{~kJ} \mathrm{~mol}^{-1}\right)$, which also includes the $\mathrm{Br} \cdots \mathrm{H}$ interaction (Fig. 5, A). Other strong contributors are the contacts with the molecule in the next pair, that is still parallel to the first pair, but only overlaps with one of its two phenyl rings $\left(-23.7 \mathrm{~kJ} \mathrm{~mol}^{-1}\right)$. This is another

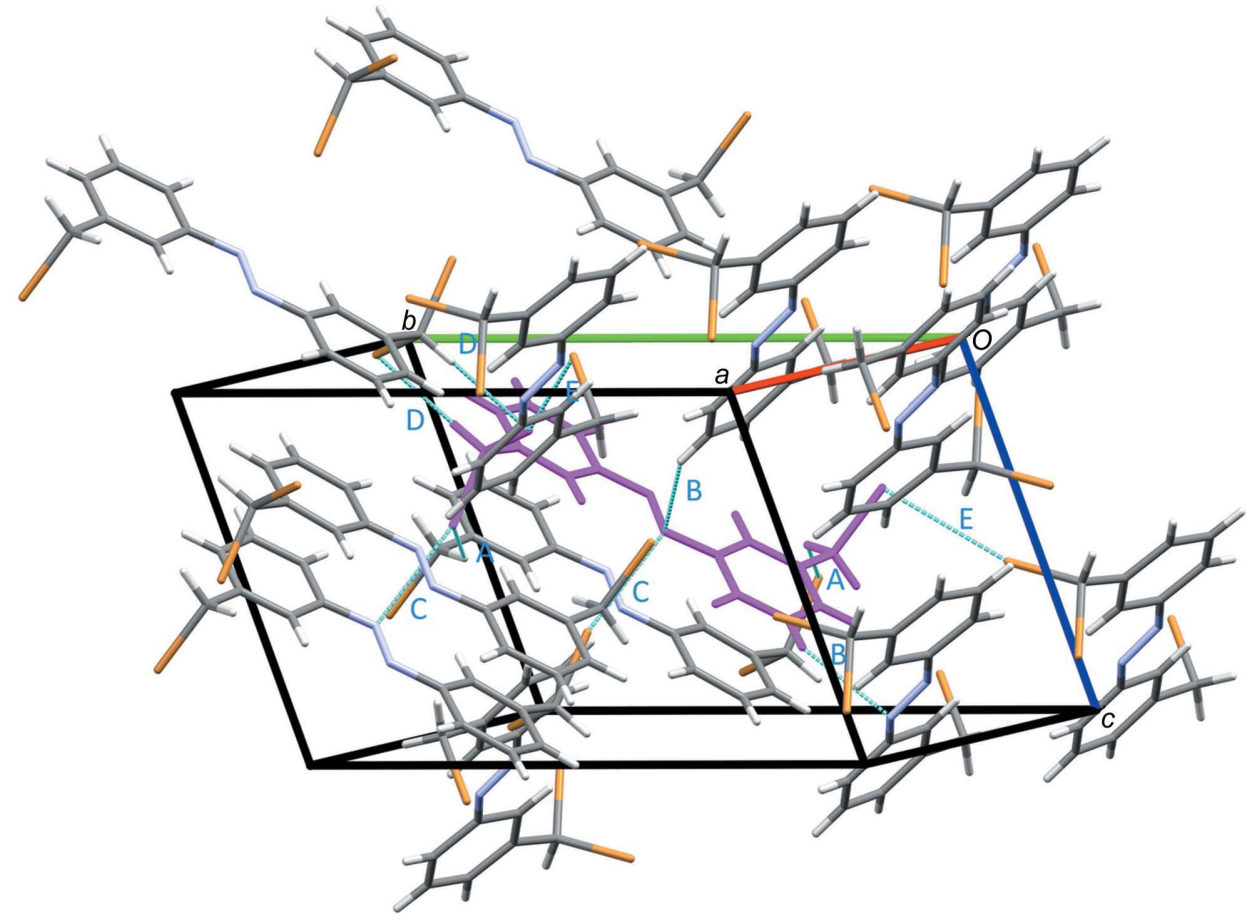

Figure 5

The crystal packing of compound 7. Contacts shorter than the van der Waals radii with the central molecule (magenta) are indicated as cyan dotted lines. The accompanying capitals refer to the contacts as specified in Table S4 of the supporting information. 
Table 6

Contact enrichment ratios in crystals of compound $\mathbf{8}$; colour coding from red to green between 0 and the maximum value in the table.

\begin{tabular}{|c|c|c|c|c|}
\hline$d_{e}$ & $\mathrm{Br}$ & $\mathrm{H}$ & C & $\mathrm{N}$ \\
\hline $\mathrm{Br}$ & 0.41 & 1.27 & 0.33 & 0.33 \\
\hline $\mathrm{H}$ & 2.03 & 0.68 & 0.95 & 0.23 \\
\hline C & 0.39 & 0.70 & 1.60 & 5.69 \\
\hline $\mathrm{N}$ & 0.33 & 0.18 & 5.69 & 0 \\
\hline
\end{tabular}

indication that the dispersion interactions are in this structure again much more important than Br-related interactions. The Type II (Desiraju \& Parthasarathy, 1989) Br..Br contact [3.5206 (7) $\AA$ and 97.5 (1) ${ }^{\circ}$, designated $\mathbf{E}$ in Fig. 5], which would feature prominently in a geometry-based discussion, is actually very low down the list of interaction strengths $\left(-5.1 \mathrm{~kJ} \mathrm{~mol}^{-1}\right)$. The stabilization for the molecule next to the pair, which features an interaction between the N2 bridge nitrogen and the dibromomethyl $\mathrm{Br} 2$ of the pair (Fig. 5, C), is $-12.9 \mathrm{~kJ} \mathrm{~mol}^{-1}$. The interaction between atoms $\mathrm{H} 7$ and $\mathrm{Br} 2$ (D in Fig. 5) is reflected in a stabilization energy of just $-11.8 \mathrm{~kJ} \mathrm{~mol}^{-1}$.

The enrichment ratios (Table 5) clearly show the full-length parallel contact, with high numbers for $\mathrm{C} \cdots \mathrm{C}(\pi-\pi)$ and $\mathrm{N} \cdots \mathrm{N}$ contacts. Also $\mathrm{H} \cdots \mathrm{Br}$ is increased, while again, $\mathrm{Br}$ atoms surprisingly seem to avoid each other.

3.1.4. Compound 8. Compound 8 contains four $\mathrm{Br}$ atoms and crystallizes in the space group $P \overline{1}$ with half a molecule in the asymmetric unit, and consequently an anti conformation around the double bond (Fig. 6). To give correct results in CLP, the half-molecule needs to be inverted and added to the CIF and the space group needs to be changed to $P 1$. The packing consists of stacks of lengthwise-displaced molecules
Table 7

Separate terms [correction factors for the 6-31(d,p) basis set already included for CE-B3LYP for comparability between the methods] in the total lattice energies according to CLP/PIXEL/MP2 and CE/B3LYP $\left(\mathrm{kJ} \mathrm{mol}{ }^{-1}\right)$.

Ele $=$ electrostatic, pol $=$ polarization, disp $=$ dispersion, rep $=$ repulsion and tot $=$ total.

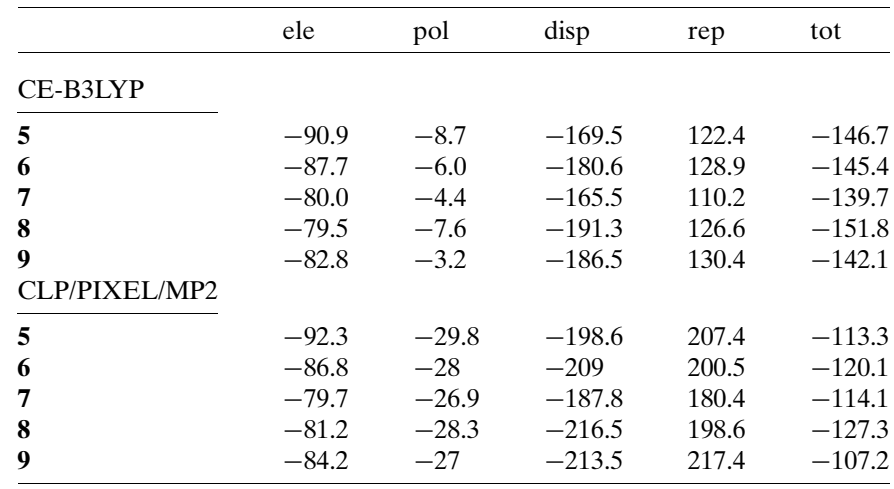

which have $\pi-\pi$ interactions combined with $\mathrm{H} \cdots \mathrm{Br}$ contacts (Fig. 6, $\mathbf{A}$ and $\mathbf{B}$ ), and $\mathrm{Br} \cdots \mathrm{Br}$ interactions between the stacks (Fig. 6, C).

We expect the $\pi$-stacked molecules along the $a c$ diagonal to have the highest stabilization $\left(-46.9 \mathrm{~kJ} \mathrm{~mol}^{-1}\right.$; interactions $\mathbf{A}$ and $\mathbf{B}$ in Fig. 6), and the stabilization for the molecules next to the stack to be much smaller. For this adjacent stack in the $b$ direction, there are no contacts shorter than the van der Waals radii for the $(x, y+1, z)$ molecule, but the stabilization is still $-21.5 \mathrm{~kJ} \mathrm{~mol}^{-1}$. For the next molecule down along $a b(x-1$, $y-1, z)$, a $\mathrm{Br} \cdots \mathrm{Br}$ contact can be seen, but it is very long $(4.04 \AA)$ and of the wrong geometry for a halogen bond. Together with the H4..Br1 interaction, this yields $-13.5 \mathrm{~kJ} \mathrm{~mol}^{-1}$. The next molecule down $(-x+2,-y+1,-z)$ is not in the CLP list of stabilizing interactions, which means its stabilization is smaller than $-3.0 \mathrm{~kJ} \mathrm{~mol}^{-1}$, and the interacting $\mathrm{Br}$ atoms that show a close contact (Fig. 6, C) may actually be forced into the repulsive region by other stronger

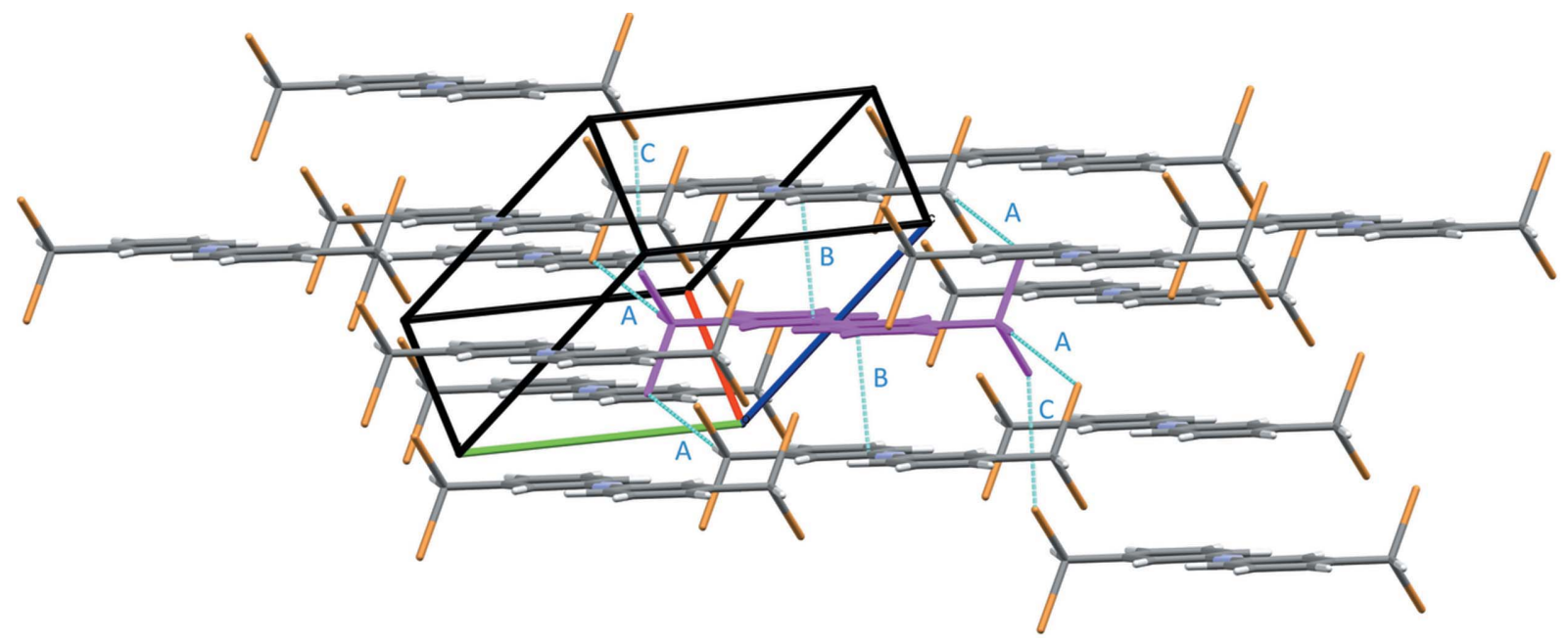

Figure 6

The crystal packing of compound $\mathbf{8}$. Contacts shorter than the van der Waals radii with the central molecule (magenta) are indicated as cyan dotted lines. The accompanying capitals refer to the contacts as specified in Table S5 of the supporting information. 
interactions. There is another contact between $\mathrm{Br} 2$ and $\mathrm{Br} 2$ at $(-x,-y+1,-z)$, which is barely longer than the van der Waals distance $(3.705 \AA$ ), and appears to have no stabilizing contribution $\left(>-3.0 \mathrm{~kJ} \mathrm{~mol}^{-1}\right)$ either. Between the layers along the $a b$ plane, interactions seem to be non-existent from a geometrical viewpoint. CLP, however, calculates intermolecular stabilization energies of $-24.2,-8.2$ and $-3.4 \mathrm{~kJ} \mathrm{~mol}^{-1}$. This is comparable with the stabilization between the columns in the $b$ direction. Overall, the stabilization energy is $-127.3 \mathrm{~kJ} \mathrm{~mol}^{-1}$ (CE-B3LYP $-151.8 \mathrm{~kJ} \mathrm{~mol}^{-1}$ ), which is the strongest among these five structures.

In this case also, the enrichment ratios (Table 6) indicate that the molecules are parallel displaced along their long axis, making $\mathrm{C}$ contact $\mathrm{N}$ and vice versa, as well as producing $\mathrm{C} \cdots \mathrm{C}$ contacts. As in compound 7, there is a larger propensity for $\mathrm{H}$ atoms to contact $\mathrm{Br}$.

3.1.5. Compound 9. Compound 9 is an approximately 50:50 merohedrally twinned crystal, in which additional disorder occurs in the orientation of the dibromomethyl groups. The space group is $P \overline{1}$, and since the molecule does not have point symmetry, the asymmetric unit is the whole molecule. The molecule contains five $\mathrm{Br}$ atoms. Since the rotational disorder of the dibromomethyl group is relatively minor $(4.7 \%)$, only the major component was retained for calculations and analysis.

The packing can be described as sideways parallel-displaced stacks of ribbons, with $\mathrm{CHBr}_{2}$ groups forming the interface between the stacks (see Fig. 7). There are plenty of apparent interactions, all of them involving $\mathrm{Br}$ (see Fig. 7, and Table S6 in the supporting information). Nevertheless, the overall lattice energy is only $-107.2 \mathrm{~kJ} \mathrm{~mol}^{-1}$ (CE-B3LYP $-142.12 \mathrm{~kJ} \mathrm{~mol}^{-1}$ ). Both repulsion and dispersion sum up to numbers slightly higher than for compound 5 (Table 7). The strongest interactions according to the CLP-PIXEL calcula-
Table 8

Contact enrichment ratios in crystals of compound $\mathbf{9}$; colour coding from red to green between 0 and the maximum value in the table.

\begin{tabular}{lllll}
\hline & & & & \\
& & & & \\
$\mathrm{d}_{\mathrm{e}}$ & $\mathrm{Br}$ & $\mathrm{H}$ & $\mathrm{C}$ & $\mathrm{N}$ \\
\hline $\mathrm{Br}$ & 0.75 & 1.24 & 0.02 & 0.91 \\
$\mathrm{H}$ & 1.87 & 0.62 & 0.80 & 0.40 \\
$\mathrm{C}$ & 0.02 & 0.79 & 4.27 & 1.37 \\
$\mathrm{~N}$ & 1.02 & 0.35 & 1.37 & 5.76 \\
\hline
\end{tabular}

tion unsurprisingly are those between the molecules above and below the ribbons. The molecules are displaced laterally over approximately half the ring diagonal, and have otherwise complete overlap. Stabilization is -42.5 and $-36.0 \mathrm{~kJ} \mathrm{~mol}^{-1}$ due to mainly the sum of the dispersion and the repulsion contributions. There are no contacts shorter than the van der Waals radii. The other interactions in Fig. 7 of Br1 with $\mathrm{H}$ and $\mathbf{N}(\mathbf{A}$ and $\mathbf{B})$, and of $\mathrm{Br} 2$ with $\mathrm{H}$ and $\mathrm{N}(\mathbf{C}, \mathbf{D}$ and $\mathbf{E})$ lead to stabilizations of -30.5 and $-22.0 \mathrm{~kJ} \mathrm{~mol}^{-1}$, respectively. This is similar to the stabilization between the central molecule and the molecule at $(-x+2,-y+1,-z+2)\left(-21.7 \mathrm{~kJ} \mathrm{~mol}^{-1}\right)$, although the latter displays no contacts shorter than the van der Waals radii by a large margin. The Type $\mathrm{I} \mathrm{Br} \cdots \mathrm{Br}$ interactions shorter than the van der Waals radii that are present in the structure (Fig. 7, $\mathbf{H}$ and $\mathbf{I}$ ) barely show up in the interaction energy list - both are at or under $-3.0 \mathrm{~kJ} \mathrm{~mol}^{-1}$ (CE interaction energy -5.3 and $>-4.0 \mathrm{~kJ} \mathrm{~mol}^{-1}$ ), but close contacts do exist from ring hydrogens to $\mathrm{Br}$ of a neighbouring molecule (Fig. 7, F and G), yielding a $-14.9 \mathrm{~kJ} \mathrm{~mol}^{-1}$ stabilization.

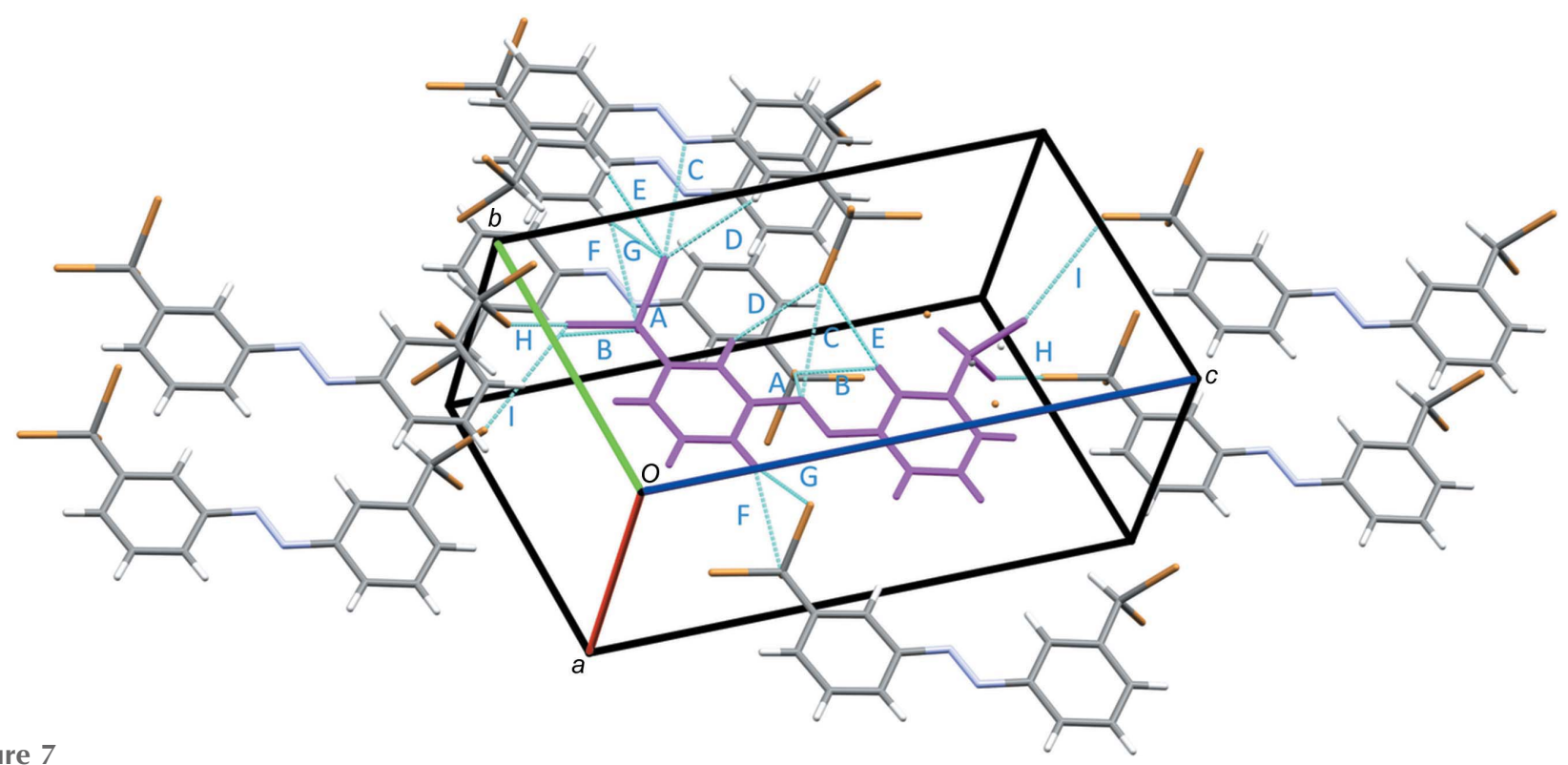

Figure 7

The crystal packing of compound 9. Contacts shorter than the van der Waals radii with the central molecule (magenta) are indicated as cyan dotted lines. The accompanying capitals refer to the contacts as specified in Table S6 of the supporting information. Unconnected dots indicate the disorder in the $\mathrm{CHBr}_{2}$ group. 


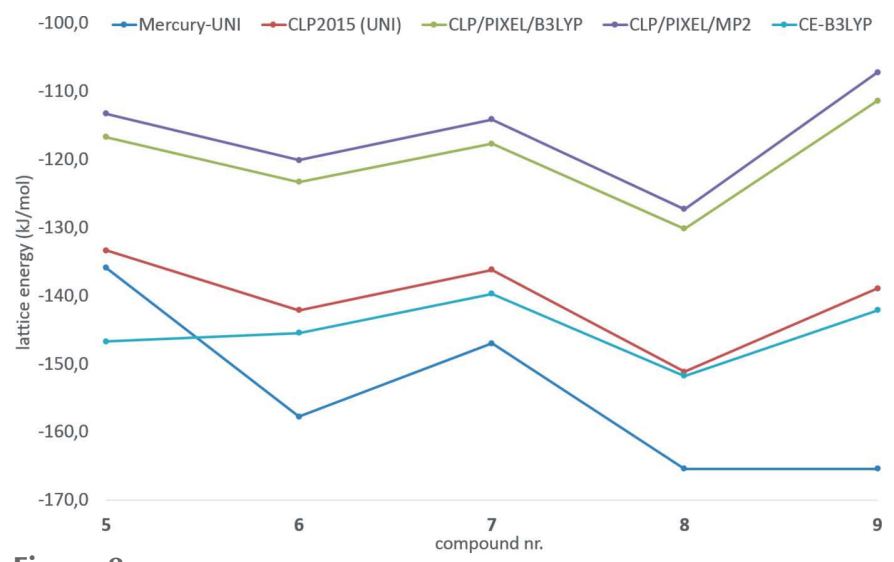

Figure 8

Calculated lattice energies $\left(\mathrm{kJ} \mathrm{mol}^{-1}\right)$ according to the various calculations made on the five brominated azobenzenes 5-9.

Again the enrichment ratios (Table 8) indicate full-length parallel contacts (displaced sideways) with even higher values for $\mathrm{C} \cdots \mathrm{C}$ and $\mathrm{N} \cdots \mathrm{N}$ due to the contact taking place on both sides of the molecule, as well as a larger propensity for $\mathrm{H}$ atoms to contact $\mathrm{Br}$, and to an extent $\mathrm{N}$ has also an increased probability of contacting $\mathrm{Br}$.

\subsection{Calculations}

3.2.1. Methods. We will briefly discuss here our experiences with the various software packages used during this work. A summary of the results is available in Fig. 8 and Table 2.

Computationally very cheap, and with the absolutely shortest learning curve, is the UNI force field calculation in Mercury (Gavezzotti, 1994; Gavezzotti \& Filippini, 1994; Macrae et al., 2008), which takes seconds or less to learn and perform. Unfortunately, the results are only suitable for obtaining a very rough idea of the intermolecular interactions.

The UNI force field atom-atom formalism in CLP (i.e. AACLP) is also very fast (on the order of seconds), but due to the input file format it takes much longer to set up correctly. The values that can be obtained, and especially the order of stability for these five compounds, are quite comparable with the more sophisticated PIXEL calculations.

CLP PIXEL requires a quantum chemical program that will write an electron-density cube. The calculation of the wave function takes some time, especially if a high level wave function and basis set are chosen (MP2 is recommended, but we found results to be quite similar using a B3LYP functional). The PIXEL calculations themselves took about $14 \mathrm{~h}$ each on a single core of an i5 $5300 \mathrm{U}$ processor at $2.3 \mathrm{GHz}$, and if multiple cores are available, multiple calculations can be run in parallel without interference.

CrystalExplorer is a much more graphical implementation of a similar idea. It comes bundled with its own quantum chemistry program, TONTO, so no external programs are needed for calculating wave functions. The final calculation takes a bit longer - typically about $2 \mathrm{~h}$ per interaction pair in the case of these molecules, again on a single core of an i5 $5300 \mathrm{U}$ processor at $2.3 \mathrm{GHz}$, and as the cluster of molecules grows, the number of interaction pairs also grows quickly. For a $10 \AA$ cluster, the largest number of different intermolecular interaction pairs was 39 for compound $\mathbf{5}$. The same remark can be made as for CLP - since the software is not written for parallel processing, several calculations can be run at the same time on several processor cores without interference.

3.2.2. Results. Table 2 and Fig. 8 list the lattice energies that result from the various calculations. It is obvious that CLPPIXEL and AA-CLP faithfully reproduce each other's order of stability for the various compounds. For CE-B3LYP, the trend is approximately the same, but especially for compound $\mathbf{5}$, a comparatively lower value for the lattice energy is found. We have been unable to find a reason for this. Both $\mathrm{CE}$ and CLP-PIXEL rely on calibration with regard to a set of (small molecule) structures for which sublimation enthalpy data are available and/or high level $a b$ initio pairwise interaction calculations or periodic calculations have been performed. For CLP, this resulted in a number of empirical constants that are taken into account in the expressions for the various terms. For $\mathrm{CE}$, the correction is made after the calculation of the separate terms, by using pre-factors to calculate a total lattice energy. These pre-factors have only been calibrated for the combinations of HF/6-31G and B3LYP/6-31(d,p) methods and basis sets. While we have used the 6-311(d,p) basis set instead, it seems unlikely that the resulting error would only affect $\mathbf{5}$. In addition, as can be seen from Table 2, the two compounds with the lowest melting points ( 7 and 9 ) also correspond to the lowest lattice stabilization energies, as calculated with $\mathrm{CE}$. This indicates that the comparative value for $\mathbf{5}$ calculated with CE could be nearer to reality than the AA-CLP and CLPPIXEL results, as the latter would suggest that the melting point of $\mathbf{5}$ should be even lower than that of $\mathbf{7}$ and $\mathbf{9}$, while it is in fact comparable to $\mathbf{6}$ and $\mathbf{8}$. The assumption that the melting point should reflect the lattice energy seems reasonable here, especially given the similarity of the five compounds studied.

Comparing between the various terms in the expressions used (see Table 7), the Coulombic term is quasi-identical within $2 \%$ between CE and CLP. CLP gives appreciably larger values for both dispersion and repulsion (by approximately $30-40 \%$ ), and the values for the polarization term show very large differences; in CLP, they are a factor 4-8 greater than in $\mathrm{CE}$ and, in absolute value, they contribute $\sim 25 \%$ to the total lattice energy. For $\mathrm{CE}$, their total contribution is only between 2 and $6 \%$.

Overall, the total lattice energies calculated by CLP are around $80 \%$ (between 75 and $85 \%$ ) of those calculated by CE.

Calculating larger and larger clusters in $\mathrm{CE}$ will only increase this difference further. The energy has probably not fully converged with the $10 \AA$ clusters used, but at least the differences become small $\left(<1 \mathrm{~kJ} \mathrm{~mol}^{-1}\right)$, as demonstrated in Fig. 2. It can also be clearly inferred from Fig. 2 that it is insufficient, when determining minimum cluster size, to be satisfied with a small number of steps that show no appreciable difference. This is due to the discrete process of taking extra molecules into account. Taking compound $\mathbf{9}$ as an example, we find that no noticeable energy difference occurs between 6 and $8.5 \AA$, but from 8.5 to $10 \AA$, there is another appreciable step in the energies, which is larger than $1 \mathrm{~kJ} \mathrm{~mol}^{-1}$ again. 


\section{Conclusions}

Halogen-halogen interactions as a substantial contributor to the lattice energies of these kinds of structures seem quite overrated, despite them very often being the current focal point in the literature. Of the five structures investigated here, only one displays what would be classified as a Type II halogen bond, which, however, turns out to have no appreciable energetic contribution to the lattice energy whatsoever.

Apart from the lack of halogen-halogen interactions, it appears that rod-shaped brominated molecules have a bewildering variety of options to pack, the diversity of which is nicely illustrated by the differently looking color-coded enrichment ratio tables. The constant factor in all of the packing systems observed is that packing in these molecules is mainly determined by molecular shape and dispersion interactions (edge-to-face $\mathrm{H} \cdots \pi$ and face-to-face $\pi-\pi$ ), and not by specific interactions involving the halogen atoms, which mainly appear to be accommodated in the lattice as well as possible.

Many new, visual and computationally cheap tools have been made available in the last few years to the molecular crystallographer. This article sums up and compares a number of them. We can conclude that for these bromomethylated azobenzenes, the AA-CLP approach is perfectly adequate for calculating a ranking of the lattice energies when compared to CLP-PIXEL, but do note that the melting points of the compounds seem to suggest that the CE energies are closer to reality, especially for compound $\mathbf{5}$.

\section{Acknowledgements}

We are grateful to $\mathrm{Mr}$ Christian Herbst (University of Bremen) for his help with the preparation of the new azobenzene derivatives in the course of his semester project and to Dr Thomas Dülcks and Ms Dorit Kemken (University of Bremen) for the mass spectrometric characterization.

\section{References}

Azov, V. A., Cordes, J., Schlüter, D., Dülcks, T., Böckmann, M. \& Doltsinis, N. L. (2014). J. Org. Chem. 79, 11714-11721.
Bruker (2009). APEX2. Bruker AXS Inc., Madison, Wisconsin, USA. Bruker (2010). SAINT and CELL_NOW. Bruker AXS Inc., Madison, Wisconsin, USA.

Desiraju, G. R. \& Parthasarathy, R. (1989). J. Am. Chem. Soc. 111, $8725-8726$.

Frisch, M. J., et al. (2016). GAUSSIAN09. Gaussian Inc., Wallingford, CT, USA. http://www.gaussian.com.

Gavezzotti, A. (1994). Acc. Chem. Res. 27, 309-314.

Gavezzotti, A. (2008). Mol. Phys. 106, 1473-1485.

Gavezzotti, A. (2011). New J. Chem. 35, 1360-1368.

Gavezzotti, A. \& Filippini, G. (1994). J. Phys. Chem. 98, 4831-4837.

Harada, J. \& Ogawa, K. (2009). Chem. Soc. Rev. 38, 2244-2252.

Hübschle, C. B., Sheldrick, G. M. \& Dittrich, B. (2011). J. Appl. Cryst. 44, 1281-1284.

Jayatilaka, D. \& Grimwood, D. J. (2003). Proceedings of Computational Science, ICCS 2003, Part IV, pp. 142-151. Melbourne, Australia, and St Petersburg, Russia, June 2-4, 2003.

Jelsch, C., Ejsmont, K. \& Huder, L. (2014). IUCrJ, 1, 119-128.

Jousselme, B., Blanchard, P., Gallego-Planas, N., Levillain, E., Delaunay, J., Allain, M., Richomme, P. \& Roncali, J. (2003). Chem. Eur. J. 9, 5297-5306.

Krause, L., Herbst-Irmer, R., Sheldrick, G. M. \& Stalke, D. (2015). J. Appl. Cryst. 48, 3-10.

Macrae, C. F., Bruno, I. J., Chisholm, J. A., Edgington, P. R., McCabe, P., Pidcock, E., Rodriguez-Monge, L., Taylor, R., van de Streek, J. \& Wood, P. A. (2008). J. Appl. Cryst. 41, 466-470.

McKinnon, J. J., Mitchell, A. S. \& Spackman, M. A. (1998). Chem. Eur. J. 4, 2136-2141.

McKinnon, J. J., Spackman, M. A. \& Mitchell, A. S. (2004). Acta Cryst. B60, 627-668.

Merino, E. (2011). Chem. Soc. Rev. 40, 3835-3853.

Metrangolo, P., Meyer, F., Pilati, T., Resnati, G. \& Terraneo, G. (2008). Angew. Chem. Int. Ed. 47, 6114-6127.

Sheldrick, G. M. (2008a). CELL_NOW. University of Göttingen, Germany.

Sheldrick, G. M. (2008b). Acta Cryst. A64, 112-122.

Sheldrick, G. M. (2012). TWINABS. University of Göttingen, Germany.

Sheldrick, G. M. (2015). Acta Cryst. C71, 3-8.

Spackman, M. A. \& McKinnon, J. J. (2002). CrystEngComm, 4, 378392.

Thomas, S. P., Spackman, P. R., Jayatilaka, D. \& Spackman, M. A. (2018). J. Chem. Theory Comput. 14, 1614-1623.

Turner, M. J., McKinnon, J. J., Wolff, S. K., Grimwood, D. J., Spackman, P. R., Jayatilaka, D. \& Spackman, M. A. (2017). CrystalExplorer17. University of Western Australia.

Vande Velde, C. M. L., Zeller, M. \& Azov, V. A. (2015). CrystEngComm, 17, 5751-5756. 


\section{supporting information}

Acta Cryst. (2018). C74, 1692-1702［https://doi.org/10.1107/S2053229618015309]

\section{Comparison of computationally cheap methods for providing insight into the crystal packing of highly bromomethylated azobenzenes}

\section{Christophe M. L. Vande Velde, Matthias Zeller and Vladimir A. Azov}

Computing details

For all structures, data collection: APEX2 (Bruker, 2009); cell refinement: SAINT (Bruker, 2009); data reduction: SAINT (Bruker, 2009); program(s) used to solve structure: SHELXS2013 (Sheldrick, 2008); program(s) used to refine structure: SHELXL2018 (Sheldrick, 2015) and shelXle(Hübschle et al., 2011); software used to prepare material for publication: SHELXL2018 (Sheldrick, 2015).

(E)-[4-(Bromomethyl) phenyl][4-(dibromomethyl) phenyl]diazene (5)

\section{Crystal data}

$\mathrm{C}_{14} \mathrm{H}_{11} \mathrm{Br}_{3} \mathrm{~N}_{2}$

$M_{r}=446.98$

Monoclinic, $P 2_{1} / c$

$a=8.538(1) \AA$

$b=5.283(1) \AA$

$c=32.801(4) \AA$

$\beta=99.692(5)^{\circ}$

$V=1458.4(4) \AA^{3}$

$Z=4$

$F(000)=856$

Data collection

Bruker SMART 1000

diffractometer

Radiation source: fine-focus sealed tube

Graphite monochromator

$\omega$ scans

Absorption correction: multi-scan

(SADABS; Krause et al., 2015)

$T_{\min }=0.316, T_{\max }=0.746$

Refinement

Refinement on $F^{2}$

Least-squares matrix: full

$R\left[F^{2}>2 \sigma\left(F^{2}\right)\right]=0.039$

$w R\left(F^{2}\right)=0.088$

$S=1.15$

4445 reflections

172 parameters

0 restraints
$D_{\mathrm{x}}=2.036 \mathrm{Mg} \mathrm{m}^{-3}$

Melting point: $146-148 \mathrm{C} \mathrm{K}$

Mo $K \alpha$ radiation, $\lambda=0.71073 \AA$

Cell parameters from 6003 reflections

$\theta=2.5-31.0^{\circ}$

$\mu=8.29 \mathrm{~mm}^{-1}$

$T=100 \mathrm{~K}$

Plate, orange

$0.45 \times 0.35 \times 0.18 \mathrm{~mm}$

13694 measured reflections

4445 independent reflections

3947 reflections with $I>2 \sigma(I)$

$R_{\text {int }}=0.040$

$\theta_{\max }=31.4^{\circ}, \theta_{\min }=2.4^{\circ}$

$h=-12 \rightarrow 12$

$k=-7 \rightarrow 7$

$l=-47 \rightarrow 46$

Primary atom site location: structure-invariant direct methods

Secondary atom site location: difference Fourier map

Hydrogen site location: inferred from neighbouring sites

$\mathrm{H}$-atom parameters constrained 


$$
\begin{array}{ll}
w=1 /\left[\sigma^{2}\left(F_{\mathrm{o}}^{2}\right)+(0.0221 P)^{2}+4.4145 P\right] & \Delta \rho_{\max }=1.41 \mathrm{e} \AA^{-3} \\
\text { where } P=\left(F_{\mathrm{o}}^{2}+2 F_{\mathrm{c}}{ }^{2}\right) / 3 & \Delta \rho_{\min }=-1.06 \mathrm{e} \AA^{-3} \\
(\Delta / \sigma)_{\max }=0.003 &
\end{array}
$$

\section{Special details}

Geometry. All e.s.d.'s (except the e.s.d. in the dihedral angle between two 1.s. planes) are estimated using the full covariance matrix. The cell e.s.d.'s are taken into account individually in the estimation of e.s.d.'s in distances, angles and torsion angles; correlations between e.s.d.'s in cell parameters are only used when they are defined by crystal symmetry. An approximate (isotropic) treatment of cell e.s.d.'s is used for estimating e.s.d.'s involving l.s. planes.

Fractional atomic coordinates and isotropic or equivalent isotropic displacement parameters $\left(\AA^{2}\right)$

\begin{tabular}{lllll}
\hline & $x$ & $y$ & $z$ & $U_{\text {iso }} * U_{\text {eq }}$ \\
\hline Br1 & $0.61597(4)$ & $1.05498(6)$ & $0.95232(2)$ & $0.01420(8)$ \\
$\mathrm{Br} 2$ & $0.92730(4)$ & $0.72243(7)$ & $0.95898(2)$ & $0.01715(9)$ \\
$\mathrm{Br} 3$ & $0.67770(4)$ & $1.00291(6)$ & $0.54184(2)$ & $0.01277(8)$ \\
$\mathrm{N} 1$ & $0.6931(4)$ & $0.7036(6)$ & $0.75752(9)$ & $0.0146(5)$ \\
$\mathrm{N} 2$ & $0.8014(4)$ & $0.8208(6)$ & $0.74401(8)$ & $0.0142(5)$ \\
$\mathrm{C} 1$ & $0.6963(4)$ & $0.7378(6)$ & $0.80072(9)$ & $0.0123(6)$ \\
$\mathrm{C} 2$ & $0.7807(4)$ & $0.9300(7)$ & $0.82415(10)$ & $0.0137(6)$ \\
$\mathrm{H} 2$ & 0.837587 & 1.052512 & 0.811275 & $0.016^{*}$ \\
$\mathrm{C} 3$ & $0.7804(4)$ & $0.9398(6)$ & $0.86638(10)$ & $0.0115(6)$ \\
$\mathrm{H} 3$ & 0.836770 & 1.070822 & 0.882433 & $0.014^{*}$ \\
$\mathrm{C} 4$ & $0.6985(4)$ & $0.7599(6)$ & $0.88542(9)$ & $0.0106(6)$ \\
$\mathrm{C} 5$ & $0.6105(4)$ & $0.5728(6)$ & $0.86189(10)$ & $0.0126(6)$ \\
$\mathrm{H} 5$ & 0.552169 & 0.452275 & 0.874761 & $0.015^{*}$ \\
$\mathrm{C} 6$ & $0.6084(4)$ & $0.5639(7)$ & $0.81934(10)$ & $0.0137(6)$ \\
$\mathrm{H} 6$ & 0.547020 & 0.438890 & 0.803044 & $0.016^{*}$ \\
$\mathrm{C} 7$ & $0.7088(4)$ & $0.7544(6)$ & $0.93152(10)$ & $0.0109(6)$ \\
$\mathrm{H} 7$ & 0.648722 & 0.603256 & 0.938825 & $0.013^{*}$ \\
$\mathrm{C} 11$ & $0.8005(4)$ & $0.7837(6)$ & $0.70107(10)$ & $0.0120(6)$ \\
$\mathrm{C} 12$ & $0.7182(4)$ & $0.5901(7)$ & $0.67781(10)$ & $0.0139(6)$ \\
$\mathrm{H} 12$ & 0.658565 & 0.471034 & 0.690584 & $0.017^{*}$ \\
$\mathrm{C} 13$ & $0.7239(4)$ & $0.5723(6)$ & $0.63590(10)$ & $0.0129(6)$ \\
$\mathrm{H} 13$ & 0.668797 & 0.439258 & 0.620078 & $0.015^{*}$ \\
$\mathrm{C} 14$ & $0.8103(4)$ & $0.7486(6)$ & $0.61663(10)$ & $0.0120(6)$ \\
$\mathrm{C} 15$ & $0.8945(4)$ & $0.9373(7)$ & $0.64037(10)$ & $0.0140(6)$ \\
$\mathrm{H} 15$ & 0.955100 & 1.055490 & 0.627698 & $0.017^{*}$ \\
$\mathrm{C} 16$ & $0.8909(4)$ & $0.9551(7)$ & $0.68238(10)$ & $0.0140(6)$ \\
$\mathrm{H} 16$ & 0.949921 & 1.083574 & 0.698432 & $0.017^{*}$ \\
$\mathrm{C} 17$ & $0.8106(4)$ & $0.7318(6)$ & $0.57118(10)$ & $0.0139(6)$ \\
$\mathrm{H} 17 \mathrm{~A}$ & 0.768991 & 0.564811 & 0.560795 & $0.017^{*}$ \\
$\mathrm{H} 17 \mathrm{~B}$ & 0.920742 & 0.747939 & 0.565756 & $0.017^{*}$ \\
& & & &
\end{tabular}

Atomic displacement parameters $\left(\AA^{2}\right)$

\begin{tabular}{lllllll}
\hline & $U^{11}$ & $U^{22}$ & $U^{\beta 3}$ & $U^{12}$ & $U^{13}$ & $U^{23}$ \\
\hline $\mathrm{Br} 1$ & $0.01541(16)$ & $0.01421(16)$ & $0.01425(15)$ & $0.00470(12)$ & $0.00615(11)$ & $-0.00083(11)$ \\
$\mathrm{Br} 2$ & $0.00833(15)$ & $0.0289(2)$ & $0.01414(15)$ & $0.00497(13)$ & $0.00154(11)$ & $0.00409(12)$
\end{tabular}




\begin{tabular}{lllllll} 
Br3 & $0.00854(15)$ & $0.01608(16)$ & $0.01370(14)$ & $-0.00059(12)$ & $0.00187(11)$ & $0.00244(11)$ \\
N1 & $0.0130(13)$ & $0.0186(14)$ & $0.0126(12)$ & $-0.0007(11)$ & $0.0031(10)$ & $0.0008(10)$ \\
N2 & $0.0145(13)$ & $0.0177(14)$ & $0.0111(12)$ & $-0.0002(11)$ & $0.0037(10)$ & $0.0001(10)$ \\
C1 & $0.0090(14)$ & $0.0173(16)$ & $0.0108(13)$ & $0.0018(12)$ & $0.0022(11)$ & $0.0003(11)$ \\
C2 & $0.0130(15)$ & $0.0151(15)$ & $0.0136(14)$ & $-0.0015(12)$ & $0.0045(12)$ & $0.0018(11)$ \\
C3 & $0.0078(14)$ & $0.0121(14)$ & $0.0151(14)$ & $-0.0030(11)$ & $0.0037(11)$ & $-0.0005(11)$ \\
C4 & $0.0076(13)$ & $0.0130(14)$ & $0.0119(13)$ & $0.0028(11)$ & $0.0039(11)$ & $0.0013(11)$ \\
C5 & $0.0078(14)$ & $0.0143(15)$ & $0.0164(14)$ & $-0.0031(12)$ & $0.0038(11)$ & $0.0008(11)$ \\
C6 & $0.0104(15)$ & $0.0167(16)$ & $0.0142(14)$ & $-0.0023(12)$ & $0.0026(11)$ & $-0.0008(12)$ \\
C7 & $0.0075(13)$ & $0.0116(14)$ & $0.0147(14)$ & $0.0013(11)$ & $0.0047(11)$ & $-0.0010(11)$ \\
C11 & $0.0083(14)$ & $0.0157(15)$ & $0.0121(13)$ & $0.0019(12)$ & $0.0015(11)$ & $0.0015(11)$ \\
C12 & $0.0126(15)$ & $0.0154(15)$ & $0.0138(14)$ & $-0.0005(12)$ & $0.0027(11)$ & $0.0019(11)$ \\
C13 & $0.0100(14)$ & $0.0141(15)$ & $0.0144(14)$ & $-0.0011(12)$ & $0.0019(11)$ & $-0.0006(11)$ \\
C14 & $0.0104(14)$ & $0.0134(15)$ & $0.0126(13)$ & $0.0028(12)$ & $0.0031(11)$ & $-0.0003(11)$ \\
C15 & $0.0104(15)$ & $0.0176(16)$ & $0.0148(14)$ & $-0.0024(12)$ & $0.0049(11)$ & $0.0005(12)$ \\
C16 & $0.0100(15)$ & $0.0181(16)$ & $0.0139(14)$ & $-0.0021(12)$ & $0.0023(11)$ & $-0.0030(12)$ \\
C17 & $0.0147(15)$ & $0.0141(15)$ & $0.0135(14)$ & $0.0023(12)$ & $0.0044(12)$ & $0.0003(11)$ \\
& & & & & & \\
\hline
\end{tabular}

Geometric parameters $\left(A,{ }^{\circ}\right)$

\begin{tabular}{llll}
\hline $\mathrm{Br} 1-\mathrm{C} 7$ & $1.948(3)$ & $\mathrm{C} 6-\mathrm{H} 6$ & 0.9500 \\
$\mathrm{Br} 2-\mathrm{C} 7$ & $1.938(3)$ & $\mathrm{C} 7-\mathrm{H} 7$ & 1.0000 \\
$\mathrm{Br} 3-\mathrm{C} 17$ & $1.974(3)$ & $\mathrm{C} 11-\mathrm{C} 12$ & $1.393(5)$ \\
$\mathrm{N} 1-\mathrm{N} 2$ & $1.254(4)$ & $\mathrm{C} 11-\mathrm{C} 16$ & $1.397(5)$ \\
$\mathrm{N} 1-\mathrm{C} 1$ & $1.424(4)$ & $\mathrm{C} 12-\mathrm{C} 13$ & $1.387(4)$ \\
$\mathrm{N} 2-\mathrm{C} 11$ & $1.421(4)$ & $\mathrm{C} 12-\mathrm{H} 12$ & 0.9500 \\
$\mathrm{C} 1-\mathrm{C} 6$ & $1.391(5)$ & $\mathrm{C} 13-\mathrm{C} 14$ & $1.403(5)$ \\
$\mathrm{C} 1-\mathrm{C} 2$ & $1.398(5)$ & $\mathrm{C} 13-\mathrm{H} 13$ & 0.9500 \\
$\mathrm{C} 2-\mathrm{C} 3$ & $1.386(4)$ & $\mathrm{C} 14-\mathrm{C} 15$ & $1.389(5)$ \\
$\mathrm{C} 2-\mathrm{H} 2$ & 0.9500 & $\mathrm{C} 14-\mathrm{C} 17$ & $1.494(4)$ \\
$\mathrm{C} 3-\mathrm{C} 4$ & $1.389(4)$ & $\mathrm{C} 15-\mathrm{C} 16$ & $1.387(4)$ \\
$\mathrm{C} 3-\mathrm{H} 3$ & 0.9500 & $\mathrm{C} 15-\mathrm{H} 15$ & 0.9500 \\
$\mathrm{C} 4-\mathrm{C} 5$ & $1.394(5)$ & $\mathrm{C} 16-\mathrm{H} 16$ & 0.9500 \\
$\mathrm{C} 4-\mathrm{C} 7$ & $1.500(4)$ & $\mathrm{C} 17-\mathrm{H} 17 \mathrm{~A}$ & 0.9900 \\
$\mathrm{C} 5-\mathrm{C} 6$ & $1.394(4)$ & & 0.9900 \\
$\mathrm{C} 5-\mathrm{H} 5$ & 0.9500 & $\mathrm{~B} 17-\mathrm{H} 17 \mathrm{~B}$ & 108.2 \\
& & $\mathrm{C} 12-\mathrm{C} 7-\mathrm{C} 11-\mathrm{C} 16$ & $120.0(3)$ \\
$\mathrm{N} 2-\mathrm{N} 1-\mathrm{C} 1$ & $113.4(3)$ & $\mathrm{C} 12-\mathrm{C} 11-\mathrm{N} 2$ & $124.2(3)$ \\
$\mathrm{N} 1-\mathrm{N} 2-\mathrm{C} 11$ & $113.6(3)$ & $\mathrm{C} 16-\mathrm{C} 11-\mathrm{N} 2$ & $115.7(3)$ \\
$\mathrm{C} 6-\mathrm{C} 1-\mathrm{C} 2$ & $120.3(3)$ & $\mathrm{C} 13-\mathrm{C} 12-\mathrm{C} 11$ & $119.6(3)$ \\
$\mathrm{C} 6-\mathrm{C} 1-\mathrm{N} 1$ & $115.6(3)$ & $\mathrm{C} 13-\mathrm{C} 12-\mathrm{H} 12$ & 120.2 \\
$\mathrm{C} 2-\mathrm{C} 1-\mathrm{N} 1$ & $124.1(3)$ & $\mathrm{C} 11-\mathrm{C} 12-\mathrm{H} 12$ & 120.2 \\
$\mathrm{C} 3-\mathrm{C} 2-\mathrm{C} 1$ & $119.3(3)$ & $\mathrm{C} 12-\mathrm{C} 13-\mathrm{C} 14$ & $120.7(3)$ \\
$\mathrm{C} 3-\mathrm{C} 2-\mathrm{H} 2$ & 120.4 & $\mathrm{C} 14-\mathrm{C} 13-\mathrm{H} 13$ & 119.7 \\
$\mathrm{C} 1-\mathrm{C} 2-\mathrm{H} 2$ & 120.4 & & 119.7 \\
$\mathrm{C} 2-\mathrm{C} 3-\mathrm{C} 4$ & $120.6(3)$ & $119.7(3)$ \\
$\mathrm{C} 2-\mathrm{C} 3-\mathrm{H} 3$ & 119.7 & & \\
$\mathrm{C} 4-\mathrm{C} 3-\mathrm{H} 3$ & & & \\
& & &
\end{tabular}




\begin{tabular}{|c|c|c|c|}
\hline $\mathrm{C} 3-\mathrm{C} 4-\mathrm{C} 5$ & $120.1(3)$ & $\mathrm{C} 15-\mathrm{C} 14-\mathrm{C} 17$ & $120.9(3)$ \\
\hline $\mathrm{C} 3-\mathrm{C} 4-\mathrm{C} 7$ & $121.2(3)$ & $\mathrm{C} 13-\mathrm{C} 14-\mathrm{C} 17$ & $120.0(3)$ \\
\hline $\mathrm{C} 5-\mathrm{C} 4-\mathrm{C} 7$ & $118.6(3)$ & $\mathrm{C} 16-\mathrm{C} 15-\mathrm{C} 14$ & $120.6(3)$ \\
\hline $\mathrm{C} 6-\mathrm{C} 5-\mathrm{C} 4$ & $119.6(3)$ & $\mathrm{C} 16-\mathrm{C} 15-\mathrm{H} 15$ & 119.7 \\
\hline $\mathrm{C} 6-\mathrm{C} 5-\mathrm{H} 5$ & 120.2 & $\mathrm{C} 14-\mathrm{C} 15-\mathrm{H} 15$ & 119.7 \\
\hline $\mathrm{C} 4-\mathrm{C} 5-\mathrm{H} 5$ & 120.2 & $\mathrm{C} 15-\mathrm{C} 16-\mathrm{C} 11$ & $119.9(3)$ \\
\hline $\mathrm{C} 1-\mathrm{C} 6-\mathrm{C} 5$ & $120.0(3)$ & $\mathrm{C} 15-\mathrm{C} 16-\mathrm{H} 16$ & 120.0 \\
\hline $\mathrm{C} 1-\mathrm{C} 6-\mathrm{H} 6$ & 120.0 & $\mathrm{C} 11-\mathrm{C} 16-\mathrm{H} 16$ & 120.0 \\
\hline $\mathrm{C} 5-\mathrm{C} 6-\mathrm{H} 6$ & 120.0 & $\mathrm{C} 14-\mathrm{C} 17-\mathrm{Br} 3$ & $110.3(2)$ \\
\hline $\mathrm{C} 4-\mathrm{C} 7-\mathrm{Br} 2$ & $111.0(2)$ & $\mathrm{C} 14-\mathrm{C} 17-\mathrm{H} 17 \mathrm{~A}$ & 109.6 \\
\hline $\mathrm{C} 4-\mathrm{C} 7-\mathrm{Br} 1$ & $112.3(2)$ & $\mathrm{Br} 3-\mathrm{C} 17-\mathrm{H} 17 \mathrm{~A}$ & 109.6 \\
\hline $\mathrm{Br} 2-\mathrm{C} 7-\mathrm{Br} 1$ & $108.96(15)$ & $\mathrm{C} 14-\mathrm{C} 17-\mathrm{H} 17 \mathrm{~B}$ & 109.6 \\
\hline $\mathrm{C} 4-\mathrm{C} 7-\mathrm{H} 7$ & 108.2 & $\mathrm{Br} 3-\mathrm{C} 17-\mathrm{H} 17 \mathrm{~B}$ & 109.6 \\
\hline $\mathrm{Br} 2-\mathrm{C} 7-\mathrm{H} 7$ & 108.2 & $\mathrm{H} 17 \mathrm{~A}-\mathrm{C} 17-\mathrm{H} 17 \mathrm{~B}$ & 108.1 \\
\hline $\mathrm{C} 1-\mathrm{N} 1-\mathrm{N} 2-\mathrm{C} 11$ & $178.9(3)$ & $\mathrm{C} 5-\mathrm{C} 4-\mathrm{C} 7-\mathrm{Br} 1$ & $-117.6(3)$ \\
\hline $\mathrm{N} 2-\mathrm{N} 1-\mathrm{C} 1-\mathrm{C} 6$ & $-163.6(3)$ & $\mathrm{N} 1-\mathrm{N} 2-\mathrm{C} 11-\mathrm{C} 12$ & $-16.0(5)$ \\
\hline $\mathrm{N} 2-\mathrm{N} 1-\mathrm{C} 1-\mathrm{C} 2$ & $16.2(5)$ & $\mathrm{N} 1-\mathrm{N} 2-\mathrm{C} 11-\mathrm{C} 16$ & $164.7(3)$ \\
\hline $\mathrm{C} 6-\mathrm{C} 1-\mathrm{C} 2-\mathrm{C} 3$ & $2.3(5)$ & $\mathrm{C} 16-\mathrm{C} 11-\mathrm{C} 12-\mathrm{C} 13$ & $-1.4(5)$ \\
\hline $\mathrm{N} 1-\mathrm{C} 1-\mathrm{C} 2-\mathrm{C} 3$ & $-177.5(3)$ & $\mathrm{N} 2-\mathrm{C} 11-\mathrm{C} 12-\mathrm{C} 13$ & $179.4(3)$ \\
\hline $\mathrm{C} 1-\mathrm{C} 2-\mathrm{C} 3-\mathrm{C} 4$ & $0.6(5)$ & $\mathrm{C} 11-\mathrm{C} 12-\mathrm{C} 13-\mathrm{C} 14$ & $-0.7(5)$ \\
\hline $\mathrm{C} 2-\mathrm{C} 3-\mathrm{C} 4-\mathrm{C} 5$ & $-2.5(5)$ & $\mathrm{C} 12-\mathrm{C} 13-\mathrm{C} 14-\mathrm{C} 15$ & $2.0(5)$ \\
\hline $\mathrm{C} 2-\mathrm{C} 3-\mathrm{C} 4-\mathrm{C} 7$ & $174.6(3)$ & $\mathrm{C} 12-\mathrm{C} 13-\mathrm{C} 14-\mathrm{C} 17$ & $-177.9(3)$ \\
\hline $\mathrm{C} 3-\mathrm{C} 4-\mathrm{C} 5-\mathrm{C} 6$ & $1.6(5)$ & $\mathrm{C} 13-\mathrm{C} 14-\mathrm{C} 15-\mathrm{C} 16$ & $-1.3(5)$ \\
\hline $\mathrm{C} 7-\mathrm{C} 4-\mathrm{C} 5-\mathrm{C} 6$ & $-175.5(3)$ & $\mathrm{C} 17-\mathrm{C} 14-\mathrm{C} 15-\mathrm{C} 16$ & $178.6(3)$ \\
\hline $\mathrm{C} 2-\mathrm{C} 1-\mathrm{C} 6-\mathrm{C} 5$ & $-3.2(5)$ & $\mathrm{C} 14-\mathrm{C} 15-\mathrm{C} 16-\mathrm{C} 11$ & $-0.8(5)$ \\
\hline $\mathrm{N} 1-\mathrm{C} 1-\mathrm{C} 6-\mathrm{C} 5$ & $176.7(3)$ & $\mathrm{C} 12-\mathrm{C} 11-\mathrm{C} 16-\mathrm{C} 15$ & $2.1(5)$ \\
\hline $\mathrm{C} 4-\mathrm{C} 5-\mathrm{C} 6-\mathrm{C} 1$ & $1.2(5)$ & $\mathrm{N} 2-\mathrm{C} 11-\mathrm{C} 16-\mathrm{C} 15$ & $-178.6(3)$ \\
\hline $\mathrm{C} 3-\mathrm{C} 4-\mathrm{C} 7-\mathrm{Br} 2$ & $-57.0(4)$ & $\mathrm{C} 15-\mathrm{C} 14-\mathrm{C} 17-\mathrm{Br} 3$ & $-73.7(4)$ \\
\hline $\mathrm{C} 5-\mathrm{C} 4-\mathrm{C} 7-\mathrm{Br} 2$ & $120.1(3)$ & $\mathrm{C} 13-\mathrm{C} 14-\mathrm{C} 17-\mathrm{Br} 3$ & $106.1(3)$ \\
\hline $\mathrm{C} 3-\mathrm{C} 4-\mathrm{C} 7-\mathrm{Br} 1$ & $65.3(4)$ & & \\
\hline
\end{tabular}

(E)-1,2-Bis[4-(dibromomethyl)phenyl] diazene (6)

\section{Crystal data}

$\mathrm{C}_{14} \mathrm{H}_{10} \mathrm{Br}_{4} \mathrm{~N}_{2}$

$M_{r}=525.88$

Monoclinic, $C 2 / c$

$a=20.379(3) \AA$

$b=8.6401(10) \AA$

$c=9.8451(10) \AA$

$\beta=114.797(2)^{\circ}$

$V=1573.7(3) \AA^{3}$

$Z=4$

$F(000)=992$

\section{Data collection}

Bruker SMART 1000

diffractometer

Radiation source: fine-focus sealed tube
$D_{\mathrm{x}}=2.220 \mathrm{Mg} \mathrm{m}^{-3}$

Melting point: $151-153 \mathrm{C} \mathrm{K}$

Mo $K \alpha$ radiation, $\lambda=0.71073 \AA$

Cell parameters from 2626 reflections

$\theta=2.4-30.9^{\circ}$

$\mu=10.22 \mathrm{~mm}^{-1}$

$T=100 \mathrm{~K}$

Block, red

$0.51 \times 0.48 \times 0.38 \mathrm{~mm}$

Graphite monochromator

$\omega$ scans 
Absorption correction: multi-scan

(SADABS; Krause et al., 2015)

$T_{\min }=0.406, T_{\max }=0.746$

5663 measured reflections

2322 independent reflections

2049 reflections with $I>2 \sigma(I)$

\section{Refinement}

Refinement on $F^{2}$

Least-squares matrix: full

$R\left[F^{2}>2 \sigma\left(F^{2}\right)\right]=0.024$

$w R\left(F^{2}\right)=0.056$

$S=1.02$

2322 reflections

92 parameters

0 restraints

Primary atom site location: structure-invariant direct methods

Secondary atom site location: difference Fourier map

$$
\begin{aligned}
& R_{\text {int }}=0.028 \\
& \theta_{\max }=31.2^{\circ}, \theta_{\min }=2.2^{\circ} \\
& h=-24 \rightarrow 29 \\
& k=-12 \rightarrow 12 \\
& l=-14 \rightarrow 13
\end{aligned}
$$

Hydrogen site location: inferred from neighbouring sites

$\mathrm{H}$-atom parameters constrained

$w=1 /\left[\sigma^{2}\left(F_{\mathrm{o}}^{2}\right)+(0.0249 P)^{2}+1.3279 P\right]$

where $P=\left(F_{\mathrm{o}}^{2}+2 F_{\mathrm{c}}^{2}\right) / 3$

$(\Delta / \sigma)_{\max }=0.002$

$\Delta \rho_{\max }=0.82$ e $\AA^{-3}$

$\Delta \rho_{\min }=-0.60$ e $\AA^{-3}$

Extinction correction: SHELXL2018

(Sheldrick, 2015),

$\mathrm{Fc}^{*}=\mathrm{kFc}\left[1+0.001 \mathrm{xFc}^{2} \lambda^{3} / \sin (2 \theta)\right]^{-1 / 4}$

Extinction coefficient: 0.00183 (16)

\section{Special details}

Geometry. All e.s.d.'s (except the e.s.d. in the dihedral angle between two 1.s. planes) are estimated using the full covariance matrix. The cell e.s.d.'s are taken into account individually in the estimation of e.s.d.'s in distances, angles and torsion angles; correlations between e.s.d.'s in cell parameters are only used when they are defined by crystal symmetry. An approximate (isotropic) treatment of cell e.s.d.'s is used for estimating e.s.d.'s involving l.s. planes.

Fractional atomic coordinates and isotropic or equivalent isotropic displacement parameters $\left(\AA^{2}\right)$

\begin{tabular}{lllll}
\hline & $x$ & $y$ & $z$ & $U_{\text {iso }} * / U_{\text {eq }}$ \\
\hline Br1 & $0.23156(2)$ & $0.44833(3)$ & $0.27413(3)$ & $0.01427(7)$ \\
Br2 & $0.36677(2)$ & $0.26407(2)$ & $0.50812(3)$ & $0.01505(8)$ \\
N1 & $0.48068(10)$ & $0.9973(2)$ & $0.5356(2)$ & $0.0120(4)$ \\
C1 & $0.44107(11)$ & $0.8564(2)$ & $0.5167(2)$ & $0.0096(4)$ \\
C2 & $0.44206(13)$ & $0.7356(2)$ & $0.4222(3)$ & $0.0124(4)$ \\
H2 & 0.470686 & 0.743489 & 0.367280 & $0.015^{*}$ \\
C3 & $0.40098(13)$ & $0.6056(2)$ & $0.4103(3)$ & $0.0124(4)$ \\
H3 & 0.401720 & 0.522915 & 0.347309 & $0.015^{*}$ \\
C4 & $0.35791(12)$ & $0.5935(2)$ & $0.4902(2)$ & $0.0102(4)$ \\
C5 & $0.35691(12)$ & $0.7138(2)$ & $0.5828(3)$ & $0.0116(4)$ \\
H5 & 0.327697 & 0.706657 & 0.636582 & $0.014^{*}$ \\
C6 & $0.39902(12)$ & $0.8452(2)$ & $0.5966(3)$ & $0.0119(4)$ \\
H6 & 0.398937 & 0.927179 & 0.660821 & $0.014^{*}$ \\
C7 & $0.31141(13)$ & $0.4548(2)$ & $0.4738(3)$ & $0.0118(4)$ \\
H7 & 0.290721 & 0.461829 & 0.549495 & $0.014^{*}$ \\
& & & & \\
\hline
\end{tabular}

Atomic displacement parameters $\left(\AA^{2}\right)$

\begin{tabular}{lllllll}
\hline & $U^{11}$ & $U^{22}$ & $U^{33}$ & $U^{12}$ & $U^{13}$ & $U^{23}$ \\
\hline Br1 & $0.00683(12)$ & $0.01807(11)$ & $0.01567(13)$ & $-0.00205(7)$ & $0.00252(9)$ & $-0.00163(8)$ \\
$\operatorname{Br} 2$ & $0.01663(14)$ & $0.00894(10)$ & $0.01627(13)$ & $-0.00040(7)$ & $0.00363(10)$ & $0.00142(7)$
\end{tabular}




\begin{tabular}{lllllll} 
N1 & $0.0100(10)$ & $0.0096(7)$ & $0.0146(10)$ & $-0.0021(6)$ & $0.0032(8)$ & $0.0006(6)$ \\
C1 & $0.0058(10)$ & $0.0094(8)$ & $0.0104(10)$ & $-0.0015(7)$ & $0.0004(8)$ & $0.0003(7)$ \\
C2 & $0.0119(11)$ & $0.0125(9)$ & $0.0136(11)$ & $-0.0025(8)$ & $0.0060(9)$ & $-0.0026(8)$ \\
C3 & $0.0133(11)$ & $0.0110(9)$ & $0.0138(11)$ & $-0.0019(7)$ & $0.0065(9)$ & $-0.0031(7)$ \\
C4 & $0.0079(10)$ & $0.0092(8)$ & $0.0113(10)$ & $-0.0019(7)$ & $0.0017(8)$ & $0.0006(7)$ \\
C5 & $0.0103(11)$ & $0.0122(9)$ & $0.0129(11)$ & $-0.0010(7)$ & $0.0055(9)$ & $0.0007(7)$ \\
C6 & $0.0115(11)$ & $0.0103(8)$ & $0.0133(11)$ & $-0.0006(7)$ & $0.0046(9)$ & $-0.0009(7)$ \\
C7 & $0.0111(11)$ & $0.0104(9)$ & $0.0144(11)$ & $-0.0023(7)$ & $0.0057(9)$ & $-0.0021(7)$ \\
\hline
\end{tabular}

Geometric parameters $(\AA, \stackrel{\circ}{)})$

\begin{tabular}{|c|c|c|c|}
\hline $\mathrm{Br} 1-\mathrm{C} 7$ & $1.958(2)$ & $\mathrm{C} 3-\mathrm{C} 4$ & $1.407(3)$ \\
\hline $\mathrm{Br} 2-\mathrm{C} 7$ & $1.945(2)$ & $\mathrm{C} 3-\mathrm{H} 3$ & 0.9500 \\
\hline $\mathrm{N} 1-\mathrm{N} 1^{\mathrm{i}}$ & $1.255(4)$ & $\mathrm{C} 4-\mathrm{C} 5$ & $1.388(3)$ \\
\hline $\mathrm{N} 1-\mathrm{C} 1$ & $1.429(3)$ & $\mathrm{C} 4-\mathrm{C} 7$ & $1.494(3)$ \\
\hline $\mathrm{C} 1-\mathrm{C} 6$ & $1.389(3)$ & $\mathrm{C} 5-\mathrm{C} 6$ & $1.395(3)$ \\
\hline $\mathrm{C} 1-\mathrm{C} 2$ & $1.404(3)$ & $\mathrm{C} 5-\mathrm{H} 5$ & 0.9500 \\
\hline $\mathrm{C} 2-\mathrm{C} 3$ & $1.376(3)$ & $\mathrm{C} 6-\mathrm{H} 6$ & 0.9500 \\
\hline $\mathrm{C} 2-\mathrm{H} 2$ & 0.9500 & $\mathrm{C} 7-\mathrm{H} 7$ & 1.0000 \\
\hline $\mathrm{N} 1-\mathrm{i} 1-\mathrm{C} 1$ & $114.3(2)$ & $\mathrm{C} 4-\mathrm{C} 5-\mathrm{C} 6$ & $119.7(2)$ \\
\hline $\mathrm{C} 6-\mathrm{C} 1-\mathrm{C} 2$ & 120.49 (19) & $\mathrm{C} 4-\mathrm{C} 5-\mathrm{H} 5$ & 120.2 \\
\hline $\mathrm{C} 6-\mathrm{C} 1-\mathrm{N} 1$ & 115.77 (18) & $\mathrm{C} 6-\mathrm{C} 5-\mathrm{H} 5$ & 120.2 \\
\hline $\mathrm{C} 2-\mathrm{C} 1-\mathrm{N} 1$ & $123.7(2)$ & $\mathrm{C} 1-\mathrm{C} 6-\mathrm{C} 5$ & $120.2(2)$ \\
\hline $\mathrm{C} 3-\mathrm{C} 2-\mathrm{C} 1$ & $119.1(2)$ & $\mathrm{C} 1-\mathrm{C} 6-\mathrm{H} 6$ & 119.9 \\
\hline $\mathrm{C} 3-\mathrm{C} 2-\mathrm{H} 2$ & 120.5 & $\mathrm{C} 5-\mathrm{C} 6-\mathrm{H} 6$ & 119.9 \\
\hline $\mathrm{C} 1-\mathrm{C} 2-\mathrm{H} 2$ & 120.5 & $\mathrm{C} 4-\mathrm{C} 7-\mathrm{Br} 2$ & $111.44(16)$ \\
\hline $\mathrm{C} 2-\mathrm{C} 3-\mathrm{C} 4$ & $120.8(2)$ & $\mathrm{C} 4-\mathrm{C} 7-\mathrm{Br} 1$ & $110.73(15)$ \\
\hline $\mathrm{C} 2-\mathrm{C} 3-\mathrm{H} 3$ & 119.6 & $\mathrm{Br} 2-\mathrm{C} 7-\mathrm{Br} 1$ & $109.11(10)$ \\
\hline $\mathrm{C} 4-\mathrm{C} 3-\mathrm{H} 3$ & 119.6 & $\mathrm{C} 4-\mathrm{C} 7-\mathrm{H} 7$ & 108.5 \\
\hline $\mathrm{C} 5-\mathrm{C} 4-\mathrm{C} 3$ & $119.76(19)$ & $\mathrm{Br} 2-\mathrm{C} 7-\mathrm{H} 7$ & 108.5 \\
\hline $\mathrm{C} 5-\mathrm{C} 4-\mathrm{C} 7$ & $119.2(2)$ & $\mathrm{Br} 1-\mathrm{C} 7-\mathrm{H} 7$ & 108.5 \\
\hline $\mathrm{C} 3-\mathrm{C} 4-\mathrm{C} 7$ & $120.99(19)$ & & \\
\hline $\mathrm{N} 1{ }^{\mathrm{i}}-\mathrm{N} 1-\mathrm{C} 1-\mathrm{C} 6$ & $178.6(2)$ & $\mathrm{C} 7-\mathrm{C} 4-\mathrm{C} 5-\mathrm{C} 6$ & $-178.7(2)$ \\
\hline $\mathrm{N} 1{ }^{\mathrm{i}}-\mathrm{N} 1-\mathrm{C} 1-\mathrm{C} 2$ & $-2.6(4)$ & $\mathrm{C} 2-\mathrm{C} 1-\mathrm{C} 6-\mathrm{C} 5$ & $-0.4(3)$ \\
\hline $\mathrm{C} 6-\mathrm{C} 1-\mathrm{C} 2-\mathrm{C} 3$ & $-0.2(3)$ & $\mathrm{N} 1-\mathrm{C} 1-\mathrm{C} 6-\mathrm{C} 5$ & $178.4(2)$ \\
\hline $\mathrm{N} 1-\mathrm{C} 1-\mathrm{C} 2-\mathrm{C} 3$ & $-179.0(2)$ & $\mathrm{C} 4-\mathrm{C} 5-\mathrm{C} 6-\mathrm{C} 1$ & $0.8(3)$ \\
\hline $\mathrm{C} 1-\mathrm{C} 2-\mathrm{C} 3-\mathrm{C} 4$ & $0.6(3)$ & $\mathrm{C} 5-\mathrm{C} 4-\mathrm{C} 7-\mathrm{Br} 2$ & $-128.80(19)$ \\
\hline $\mathrm{C} 2-\mathrm{C} 3-\mathrm{C} 4-\mathrm{C} 5$ & $-0.3(3)$ & $\mathrm{C} 3-\mathrm{C} 4-\mathrm{C} 7-\mathrm{Br} 2$ & $52.9(3)$ \\
\hline $\mathrm{C} 2-\mathrm{C} 3-\mathrm{C} 4-\mathrm{C} 7$ & $178.0(2)$ & $\mathrm{C} 5-\mathrm{C} 4-\mathrm{C} 7-\mathrm{Br} 1$ & $109.6(2)$ \\
\hline $\mathrm{C} 3-\mathrm{C} 4-\mathrm{C} 5-\mathrm{C} 6$ & $-0.4(3)$ & $\mathrm{C} 3-\mathrm{C} 4-\mathrm{C} 7-\mathrm{Br} 1$ & $-68.7(2)$ \\
\hline
\end{tabular}

Symmetry code: (i) $-x+1,-y+2,-z+1$. 
(E)-[3-(Bromomethyl)phenyl][3-(dibromomethyl)phenyl]diazene (7)

Crystal data

$\mathrm{C}_{14} \mathrm{H}_{11} \mathrm{Br}_{3} \mathrm{~N}_{2}$

$M_{r}=446.98$

Monoclinic, $P 2_{1} / c$

$a=9.1219(12) \AA$

$b=16.904(2) \AA$

$c=10.3633(14) \AA$

$\beta=112.122(2)^{\circ}$

$V=1480.4(3) \AA^{3}$

$Z=4$

$F(000)=856$

$D_{\mathrm{x}}=2.006 \mathrm{Mg} \mathrm{m}^{-3}$

Melting point: $120-121 \mathrm{C} \mathrm{K}$

Mo $K \alpha$ radiation, $\lambda=0.71073 \AA$

Cell parameters from 3951 reflections

$\theta=2.4-30.6^{\circ}$

$\mu=8.16 \mathrm{~mm}^{-1}$

$T=100 \mathrm{~K}$

Plate, orange

$0.52 \times 0.45 \times 0.15 \mathrm{~mm}$

Data collection

Bruker SMART 1000

diffractometer

Radiation source: fine-focus sealed tube

measured reflections

4362 independent reflections

3587 reflections with $I>2 \sigma(I)$

Graphite monochromator

$R_{\text {int }}=0.038$

$\omega$ scans

Absorption correction: multi-scan

$\theta_{\max }=31.2^{\circ}, \theta_{\min }=2.4^{\circ}$

$h=-12 \rightarrow 9$

(SADABS; Krause et al., 2015)

$k=-23 \rightarrow 23$

$T_{\min }=0.349, T_{\max }=0.746$

$l=-15 \rightarrow 14$

Refinement

Refinement on $F^{2}$

Least-squares matrix: full

$R\left[F^{2}>2 \sigma\left(F^{2}\right)\right]=0.041$

$w R\left(F^{2}\right)=0.104$

$S=1.03$

4362 reflections

172 parameters

0 restraints

Primary atom site location: structure-invariant direct methods

Secondary atom site location: difference Fourier map

Hydrogen site location: inferred from neighbouring sites

$\mathrm{H}$-atom parameters constrained

$w=1 /\left[\sigma^{2}\left(F_{\mathrm{o}}^{2}\right)+(0.0501 P)^{2}+3.0958 P\right]$

where $P=\left(F_{\mathrm{o}}^{2}+2 F_{\mathrm{c}}^{2}\right) / 3$

$(\Delta / \sigma)_{\max }=0.001$

$\Delta \rho_{\max }=2.24 \mathrm{e} \AA^{-3}$

$\Delta \rho_{\min }=-1.56$ e $\AA^{-3}$

Special details

Geometry. All e.s.d.'s (except the e.s.d. in the dihedral angle between two l.s. planes) are estimated using the full covariance matrix. The cell e.s.d.'s are taken into account individually in the estimation of e.s.d.'s in distances, angles and torsion angles; correlations between e.s.d.'s in cell parameters are only used when they are defined by crystal symmetry. An approximate (isotropic) treatment of cell e.s.d.'s is used for estimating e.s.d.'s involving l.s. planes.

Fractional atomic coordinates and isotropic or equivalent isotropic displacement parameters $\left(\AA^{2}\right)$

\begin{tabular}{lllll}
\hline & $x$ & $y$ & $z$ & $U_{\text {iso }} * / U_{\text {eq }}$ \\
\hline Br1 & $1.09235(4)$ & $0.54419(2)$ & $0.34234(3)$ & $0.01965(10)$ \\
$\mathrm{Br} 2$ & $0.94505(5)$ & $0.41237(2)$ & $0.11026(4)$ & $0.02092(10)$ \\
$\mathrm{Br} 3$ & $-0.00058(5)$ & $0.24139(2)$ & $0.40366(4)$ & $0.02690(11)$ \\
$\mathrm{N} 1$ & $0.4960(4)$ & $0.43930(17)$ & $0.3487(3)$ & $0.0157(6)$ \\
$\mathrm{N} 2$ & $0.5936(3)$ & $0.39273(16)$ & $0.4327(3)$ & $0.0136(5)$ \\
$\mathrm{C} 1$ & $0.5604(4)$ & $0.48745(18)$ & $0.2701(3)$ & $0.0134(6)$ \\
$\mathrm{C} 2$ & $0.7098(4)$ & $0.47785(19)$ & $0.2674(3)$ & $0.0139(6)$ \\
$\mathrm{H} 2$ & 0.779123 & 0.438302 & 0.322746 & $0.017 *$
\end{tabular}




$\begin{array}{lllll}\text { C3 } & 0.7572(4) & 0.52686(19) & 0.1825(3) & 0.0138(6) \\ \text { C4 } & 0.6551(4) & 0.58540(19) & 0.1023(3) & 0.0166(6) \\ \text { H4 } & 0.688248 & 0.618877 & 0.044799 & 0.020^{*} \\ \text { C5 } & 0.5056(4) & 0.5950(2) & 0.1060(3) & 0.0177(7) \\ \text { H5 } & 0.437065 & 0.635233 & 0.052167 & 0.021^{*} \\ \text { C6 } & 0.4570(4) & 0.54534(19) & 0.1888(3) & 0.0157(6) \\ \text { H6 } & 0.353993 & 0.550622 & 0.190390 & 0.019^{*} \\ \text { C7 } & 0.9147(4) & 0.51828(19) & 0.1700(3) & 0.0157(6) \\ \text { H7 } & 0.917280 & 0.556187 & 0.096781 & 0.019^{*} \\ \text { C11 } & 0.5242(4) & 0.34393(18) & 0.5071(3) & 0.0133(6) \\ \text { C12 } & 0.3667(4) & 0.34994(19) & 0.4934(3) & 0.0144(6) \\ \text { H12 } & 0.298856 & 0.387776 & 0.431683 & 0.017^{*} \\ \text { C13 } & 0.3095(4) & 0.3004(2) & 0.5702(3) & 0.0153(6) \\ \text { C14 } & 0.4110(4) & 0.2447(2) & 0.6609(3) & 0.0178(7) \\ \text { H14 } & 0.371548 & 0.210409 & 0.712955 & 0.021^{*} \\ \text { C15 } & 0.5673(5) & 0.2392(2) & 0.6753(3) & 0.0184(7) \\ \text { H15 } & 0.635204 & 0.201636 & 0.737713 & 0.022^{*} \\ \text { C16 } & 0.6254(4) & 0.2887(2) & 0.5980(3) & 0.0160(6) \\ \text { H16 } & 0.732794 & 0.285066 & 0.607032 & 0.019^{*} \\ \text { C17 } & 0.1423(5) & 0.3077(2) & 0.5578(4) & 0.0226(7) \\ \text { H17A } & 0.108921 & 0.363708 & 0.540690 & 0.027^{*} \\ \text { H17B } & 0.133999 & 0.291236 & 0.646449 & 0.027^{*}\end{array}$

Atomic displacement parameters $\left(\AA^{2}\right)$

\begin{tabular}{lllllll}
\hline & $U^{11}$ & $U^{22}$ & $U^{33}$ & $U^{12}$ & $U^{13}$ & $U^{23}$ \\
\hline $\mathrm{Br} 1$ & $0.00936(17)$ & $0.02557(18)$ & $0.02167(16)$ & $-0.00070(13)$ & $0.00316(13)$ & $-0.00445(13)$ \\
$\mathrm{Br} 2$ & $0.0205(2)$ & $0.01986(16)$ & $0.02431(17)$ & $0.00050(13)$ & $0.01055(14)$ & $-0.00337(12)$ \\
$\mathrm{Br} 3$ & $0.01277(19)$ & $0.0289(2)$ & $0.0310(2)$ & $-0.00430(15)$ & $-0.00094(14)$ & $0.00581(15)$ \\
$\mathrm{N} 1$ & $0.0137(15)$ & $0.0168(12)$ & $0.0150(12)$ & $-0.0008(11)$ & $0.0036(11)$ & $0.0013(10)$ \\
$\mathrm{N} 2$ & $0.0107(14)$ & $0.0148(12)$ & $0.0141(11)$ & $0.0004(10)$ & $0.0034(10)$ & $0.0010(10)$ \\
$\mathrm{C} 1$ & $0.0125(16)$ & $0.0140(13)$ & $0.0115(12)$ & $-0.0020(12)$ & $0.0021(11)$ & $-0.0012(11)$ \\
$\mathrm{C} 2$ & $0.0109(16)$ & $0.0150(14)$ & $0.0125(13)$ & $-0.0004(12)$ & $0.0006(11)$ & $0.0002(11)$ \\
$\mathrm{C} 3$ & $0.0120(16)$ & $0.0137(13)$ & $0.0122(12)$ & $0.0000(12)$ & $0.0007(11)$ & $-0.0013(11)$ \\
$\mathrm{C} 4$ & $0.0169(18)$ & $0.0144(14)$ & $0.0154(14)$ & $-0.0015(13)$ & $0.0025(13)$ & $0.0029(11)$ \\
$\mathrm{C} 5$ & $0.0152(17)$ & $0.0167(14)$ & $0.0170(14)$ & $0.0010(13)$ & $0.0012(12)$ & $0.0032(12)$ \\
$\mathrm{C} 6$ & $0.0105(16)$ & $0.0165(14)$ & $0.0172(14)$ & $-0.0001(12)$ & $0.0020(12)$ & $-0.0003(12)$ \\
$\mathrm{C} 7$ & $0.0159(17)$ & $0.0161(14)$ & $0.0144(13)$ & $-0.0018(13)$ & $0.0048(12)$ & $-0.0012(11)$ \\
$\mathrm{C} 11$ & $0.0131(16)$ & $0.0131(13)$ & $0.0122(12)$ & $-0.0024(12)$ & $0.0029(11)$ & $-0.0015(11)$ \\
$\mathrm{C} 12$ & $0.0130(16)$ & $0.0151(14)$ & $0.0133(13)$ & $0.0012(12)$ & $0.0030(12)$ & $0.0000(11)$ \\
$\mathrm{C} 13$ & $0.0128(16)$ & $0.0176(14)$ & $0.0148(13)$ & $-0.0018(12)$ & $0.0044(12)$ & $-0.0050(11)$ \\
$\mathrm{C} 14$ & $0.0171(18)$ & $0.0198(15)$ & $0.0152(14)$ & $-0.0054(14)$ & $0.0045(13)$ & $0.0003(12)$ \\
$\mathrm{C} 15$ & $0.0173(18)$ & $0.0161(14)$ & $0.0163(14)$ & $-0.0006(13)$ & $0.0001(12)$ & $0.0032(12)$ \\
$\mathrm{C} 16$ & $0.0105(16)$ & $0.0174(14)$ & $0.0177(14)$ & $-0.0027(13)$ & $0.0024(12)$ & $-0.0007(12)$ \\
$\mathrm{C} 17$ & $0.0166(19)$ & $0.0266(18)$ & $0.0269(17)$ & $-0.0027(15)$ & $0.0108(15)$ & $-0.0020(14)$ \\
& & & & & & \\
\hline
\end{tabular}


Geometric parameters $\left(A,{ }^{\circ}\right)$

\begin{tabular}{|c|c|c|c|}
\hline $\mathrm{Br} 1-\mathrm{C} 7$ & $1.957(3)$ & C6- 6 6 & 0.9500 \\
\hline $\mathrm{Br} 2-\mathrm{C} 7$ & $1.948(3)$ & $\mathrm{C} 7-\mathrm{H} 7$ & 1.0000 \\
\hline $\mathrm{Br} 3-\mathrm{C} 17$ & $1.985(4)$ & $\mathrm{C} 11-\mathrm{C} 12$ & $1.393(5)$ \\
\hline $\mathrm{N} 1-\mathrm{N} 2$ & $1.260(4)$ & $\mathrm{C} 11-\mathrm{C} 16$ & $1.398(5)$ \\
\hline $\mathrm{N} 1-\mathrm{C} 1$ & $1.425(4)$ & $\mathrm{C} 12-\mathrm{C} 13$ & $1.385(5)$ \\
\hline $\mathrm{N} 2-\mathrm{C} 11$ & $1.430(4)$ & $\mathrm{C} 12-\mathrm{H} 12$ & 0.9500 \\
\hline $\mathrm{C} 1-\mathrm{C} 2$ & $1.383(5)$ & $\mathrm{C} 13-\mathrm{C} 14$ & $1.404(5)$ \\
\hline $\mathrm{C} 1-\mathrm{C} 6$ & $1.400(5)$ & $\mathrm{C} 13-\mathrm{C} 17$ & $1.487(5)$ \\
\hline $\mathrm{C} 2-\mathrm{C} 3$ & $1.390(4)$ & $\mathrm{C} 14-\mathrm{C} 15$ & $1.380(6)$ \\
\hline $\mathrm{C} 2-\mathrm{H} 2$ & 0.9500 & C14-H14 & 0.9500 \\
\hline $\mathrm{C} 3-\mathrm{C} 4$ & $1.398(4)$ & $\mathrm{C} 15-\mathrm{C} 16$ & $1.395(5)$ \\
\hline $\mathrm{C} 3-\mathrm{C} 7$ & $1.497(5)$ & C15-H15 & 0.9500 \\
\hline $\mathrm{C} 4-\mathrm{C} 5$ & $1.388(5)$ & $\mathrm{C} 16-\mathrm{H} 16$ & 0.9500 \\
\hline $\mathrm{C} 4-\mathrm{H} 4$ & 0.9500 & C17-H17A & 0.9900 \\
\hline $\mathrm{C} 5-\mathrm{C} 6$ & $1.387(5)$ & C17-H17B & 0.9900 \\
\hline $\mathrm{C} 5-\mathrm{H} 5$ & 0.9500 & & \\
\hline $\mathrm{N} 2-\mathrm{N} 1-\mathrm{C} 1$ & $114.6(3)$ & $\mathrm{Br} 1-\mathrm{C} 7-\mathrm{H} 7$ & 107.5 \\
\hline $\mathrm{N} 1-\mathrm{N} 2-\mathrm{C} 11$ & $113.1(3)$ & $\mathrm{C} 12-\mathrm{C} 11-\mathrm{C} 16$ & $120.8(3)$ \\
\hline $\mathrm{C} 2-\mathrm{C} 1-\mathrm{C} 6$ & $121.0(3)$ & $\mathrm{C} 12-\mathrm{C} 11-\mathrm{N} 2$ & $123.5(3)$ \\
\hline $\mathrm{C} 2-\mathrm{C} 1-\mathrm{N} 1$ & $124.5(3)$ & $\mathrm{C} 16-\mathrm{C} 11-\mathrm{N} 2$ & $115.7(3)$ \\
\hline $\mathrm{C} 6-\mathrm{C} 1-\mathrm{N} 1$ & $114.4(3)$ & $\mathrm{C} 13-\mathrm{C} 12-\mathrm{C} 11$ & $119.6(3)$ \\
\hline $\mathrm{C} 1-\mathrm{C} 2-\mathrm{C} 3$ & $119.1(3)$ & $\mathrm{C} 13-\mathrm{C} 12-\mathrm{H} 12$ & 120.2 \\
\hline $\mathrm{C} 1-\mathrm{C} 2-\mathrm{H} 2$ & 120.4 & $\mathrm{C} 11-\mathrm{C} 12-\mathrm{H} 12$ & 120.2 \\
\hline $\mathrm{C} 3-\mathrm{C} 2-\mathrm{H} 2$ & 120.4 & $\mathrm{C} 12-\mathrm{C} 13-\mathrm{C} 14$ & $119.6(3)$ \\
\hline $\mathrm{C} 2-\mathrm{C} 3-\mathrm{C} 4$ & $120.1(3)$ & $\mathrm{C} 12-\mathrm{C} 13-\mathrm{C} 17$ & $119.7(3)$ \\
\hline $\mathrm{C} 2-\mathrm{C} 3-\mathrm{C} 7$ & $122.3(3)$ & $\mathrm{C} 14-\mathrm{C} 13-\mathrm{C} 17$ & $120.6(3)$ \\
\hline $\mathrm{C} 4-\mathrm{C} 3-\mathrm{C} 7$ & $117.6(3)$ & $\mathrm{C} 15-\mathrm{C} 14-\mathrm{C} 13$ & $120.8(3)$ \\
\hline $\mathrm{C} 5-\mathrm{C} 4-\mathrm{C} 3$ & $120.5(3)$ & $\mathrm{C} 15-\mathrm{C} 14-\mathrm{H} 14$ & 119.6 \\
\hline $\mathrm{C} 5-\mathrm{C} 4-\mathrm{H} 4$ & 119.7 & $\mathrm{C} 13-\mathrm{C} 14-\mathrm{H} 14$ & 119.6 \\
\hline $\mathrm{C} 3-\mathrm{C} 4-\mathrm{H} 4$ & 119.7 & $\mathrm{C} 14-\mathrm{C} 15-\mathrm{C} 16$ & $119.9(3)$ \\
\hline $\mathrm{C} 6-\mathrm{C} 5-\mathrm{C} 4$ & $119.5(3)$ & $\mathrm{C} 14-\mathrm{C} 15-\mathrm{H} 15$ & 120.1 \\
\hline $\mathrm{C} 6-\mathrm{C} 5-\mathrm{H} 5$ & 120.2 & $\mathrm{C} 16-\mathrm{C} 15-\mathrm{H} 15$ & 120.1 \\
\hline $\mathrm{C} 4-\mathrm{C} 5-\mathrm{H} 5$ & 120.2 & $\mathrm{C} 15-\mathrm{C} 16-\mathrm{C} 11$ & $119.4(3)$ \\
\hline $\mathrm{C} 5-\mathrm{C} 6-\mathrm{C} 1$ & $119.7(3)$ & $\mathrm{C} 15-\mathrm{C} 16-\mathrm{H} 16$ & 120.3 \\
\hline $\mathrm{C} 5-\mathrm{C} 6-\mathrm{H} 6$ & 120.2 & $\mathrm{C} 11-\mathrm{C} 16-\mathrm{H} 16$ & 120.3 \\
\hline $\mathrm{C} 1-\mathrm{C} 6-\mathrm{H} 6$ & 120.2 & $\mathrm{C} 13-\mathrm{C} 17-\mathrm{Br} 3$ & $111.4(2)$ \\
\hline $\mathrm{C} 3-\mathrm{C} 7-\mathrm{Br} 2$ & $111.9(2)$ & $\mathrm{C} 13-\mathrm{C} 17-\mathrm{H} 17 \mathrm{~A}$ & 109.4 \\
\hline $\mathrm{C} 3-\mathrm{C} 7-\mathrm{Br} 1$ & $113.0(2)$ & $\mathrm{Br} 3-\mathrm{C} 17-\mathrm{H} 17 \mathrm{~A}$ & 109.4 \\
\hline $\mathrm{Br} 2-\mathrm{C} 7-\mathrm{Br} 1$ & $109.14(17)$ & $\mathrm{C} 13-\mathrm{C} 17-\mathrm{H} 17 \mathrm{~B}$ & 109.4 \\
\hline $\mathrm{C} 3-\mathrm{C} 7-\mathrm{H} 7$ & 107.5 & $\mathrm{Br} 3-\mathrm{C} 17-\mathrm{H} 17 \mathrm{~B}$ & 109.4 \\
\hline $\mathrm{Br} 2-\mathrm{C} 7-\mathrm{H} 7$ & 107.5 & $\mathrm{H} 17 \mathrm{~A}-\mathrm{C} 17-\mathrm{H} 17 \mathrm{~B}$ & 108.0 \\
\hline $\mathrm{C} 1-\mathrm{N} 1-\mathrm{N} 2-\mathrm{C} 11$ & $-178.5(3)$ & $\mathrm{C} 4-\mathrm{C} 3-\mathrm{C} 7-\mathrm{Br} 1$ & $114.7(3)$ \\
\hline $\mathrm{N} 2-\mathrm{N} 1-\mathrm{C} 1-\mathrm{C} 2$ & $9.4(5)$ & $\mathrm{N} 1-\mathrm{N} 2-\mathrm{C} 11-\mathrm{C} 12$ & $-3.0(4)$ \\
\hline $\mathrm{N} 2-\mathrm{N} 1-\mathrm{C} 1-\mathrm{C} 6$ & $-173.0(3)$ & $\mathrm{N} 1-\mathrm{N} 2-\mathrm{C} 11-\mathrm{C} 16$ & $177.5(3)$ \\
\hline
\end{tabular}




$\begin{array}{llll}\mathrm{C} 6-\mathrm{C} 1-\mathrm{C} 2-\mathrm{C} 3 & 0.2(5) & \mathrm{C} 16-\mathrm{C} 11-\mathrm{C} 12-\mathrm{C} 13 & -0.3(5) \\ \mathrm{N} 1-\mathrm{C} 1-\mathrm{C} 2-\mathrm{C} 3 & 177.6(3) & \mathrm{N} 2-\mathrm{C} 11-\mathrm{C} 12-\mathrm{C} 13 & -179.7(3) \\ \mathrm{C} 1-\mathrm{C} 2-\mathrm{C} 3-\mathrm{C} 4 & 0.6(5) & \mathrm{C} 11-\mathrm{C} 12-\mathrm{C} 13-\mathrm{C} 14 & -0.1(5) \\ \mathrm{C} 1-\mathrm{C} 2-\mathrm{C} 3-\mathrm{C} 7 & -177.8(3) & \mathrm{C} 11-\mathrm{C} 12-\mathrm{C} 13-\mathrm{C} 17 & 178.8(3) \\ \mathrm{C} 2-\mathrm{C} 3-\mathrm{C} 4-\mathrm{C} 5 & -0.3(5) & \mathrm{C} 12-\mathrm{C} 13-\mathrm{C} 14-\mathrm{C} 15 & 0.5(5) \\ \mathrm{C} 7-\mathrm{C} 3-\mathrm{C} 4-\mathrm{C} 5 & 178.2(3) & \mathrm{C} 17-\mathrm{C} 13-\mathrm{C} 14-\mathrm{C} 15 & -178.3(3) \\ \mathrm{C} 3-\mathrm{C} 4-\mathrm{C} 5-\mathrm{C} 6 & -0.8(5) & \mathrm{C} 13-\mathrm{C} 14-\mathrm{C} 15-\mathrm{C} 16 & -0.7(5) \\ \mathrm{C} 4-\mathrm{C} 5-\mathrm{C} 6-\mathrm{C} 1 & 1.5(5) & \mathrm{C} 14-\mathrm{C} 15-\mathrm{C} 16-\mathrm{C} 11 & 0.3(5) \\ \mathrm{C} 2-\mathrm{C} 1-\mathrm{C} 6-\mathrm{C} 5 & -1.2(5) & \mathrm{C} 12-\mathrm{C} 11-\mathrm{C} 16-\mathrm{C} 15 & 0.2(5) \\ \mathrm{N} 1-\mathrm{C} 1-\mathrm{C} 6-\mathrm{C} 5 & -178.9(3) & \mathrm{N} 2-\mathrm{C} 11-\mathrm{C} 16-\mathrm{C} 15 & 179.6(3) \\ \mathrm{C} 2-\mathrm{C} 3-\mathrm{C} 7-\mathrm{Br} 2 & 56.7(4) & \mathrm{C} 12-\mathrm{C} 13-\mathrm{C} 17-\mathrm{Br} 3 & 88.1(3) \\ \mathrm{C} 4-\mathrm{C} 3-\mathrm{C} 7-\mathrm{Br} 2 & -121.7(3) & \mathrm{C} 14-\mathrm{C} 13-\mathrm{C} 17-\mathrm{Br} 3 & -93.0(3) \\ \mathrm{C} 2-\mathrm{C} 3-\mathrm{C} 7-\mathrm{Br} 1 & -66.9(4) & & \end{array}$

(E)-1,2-Bis[3-(dibromomethyl)phenyl]diazene (8)

$$
\begin{aligned}
& \text { Crystal data } \\
& \mathrm{C}_{14} \mathrm{H}_{10} \mathrm{Br}_{4} \mathrm{~N}_{2} \\
& M_{r}=525.88 \\
& \text { Triclinic, } P \overline{1} \\
& a=4.899(2) \AA \\
& b=8.294(2) \AA \\
& c=9.942(3) \AA \\
& \alpha=98.103(4)^{\circ} \\
& \beta=103.640(3)^{\circ} \\
& \gamma=96.650(3)^{\circ} \\
& V=384.0(2) \AA^{3} \\
& Z=1
\end{aligned}
$$

\section{Data collection}

Bruker SMART 1000 diffractometer

Radiation source: fine-focus sealed tube

Graphite monochromator

$\omega$ scans

Absorption correction: multi-scan

(SADABS; Krause et al., 2015)

$T_{\min }=0.308, T_{\max }=0.746$

\section{Refinement}

Refinement on $F^{2}$

Least-squares matrix: full

$R\left[F^{2}>2 \sigma\left(F^{2}\right)\right]=0.033$

$w R\left(F^{2}\right)=0.085$

$S=1.05$

2249 reflections

92 parameters

0 restraints

Primary atom site location: structure-invariant direct methods

Secondary atom site location: difference Fourier map
$F(000)=248$

$D_{\mathrm{x}}=2.274 \mathrm{Mg} \mathrm{m}^{-3}$

Melting point: $130-132 \mathrm{C} \mathrm{K}$

Mo $K \alpha$ radiation, $\lambda=0.71073 \AA$

Cell parameters from 2578 reflections

$\theta=2.5-31.2^{\circ}$

$\mu=10.47 \mathrm{~mm}^{-1}$

$T=100 \mathrm{~K}$

Block, red

$0.45 \times 0.25 \times 0.20 \mathrm{~mm}$

5417 measured reflections

2249 independent reflections

1993 reflections with $I>2 \sigma(I)$

$R_{\text {int }}=0.042$

$\theta_{\max }=31.2^{\circ}, \theta_{\min }=2.1^{\circ}$

$h=-6 \rightarrow 7$

$k=-11 \rightarrow 11$

$l=-14 \rightarrow 14$

Hydrogen site location: inferred from neighbouring sites

$\mathrm{H}$-atom parameters constrained

$w=1 /\left[\sigma^{2}\left(F_{\mathrm{o}}^{2}\right)+(0.0356 P)^{2}+0.5445 P\right]$

where $P=\left(F_{\mathrm{o}}^{2}+2 F_{\mathrm{c}}{ }^{2}\right) / 3$

$(\Delta / \sigma)_{\max }<0.001$

$\Delta \rho_{\max }=1.08 \mathrm{e} \AA^{-3}$

$\Delta \rho_{\min }=-1.11 \mathrm{e} \AA^{-3}$

Extinction correction: SHELXL2018

(Sheldrick, 2015),

$\mathrm{Fc}^{*}=\mathrm{kFc}\left[1+0.001 \mathrm{xFc}^{2} \lambda^{3} / \sin (2 \theta)\right]^{-1 / 4}$

Extinction coefficient: 0.022 (2) 


\section{Special details}

Geometry. All e.s.d.'s (except the e.s.d. in the dihedral angle between two 1.s. planes) are estimated using the full covariance matrix. The cell e.s.d.'s are taken into account individually in the estimation of e.s.d.'s in distances, angles and torsion angles; correlations between e.s.d.'s in cell parameters are only used when they are defined by crystal symmetry. An approximate (isotropic) treatment of cell e.s.d.'s is used for estimating e.s.d.'s involving l.s. planes.

Fractional atomic coordinates and isotropic or equivalent isotropic displacement parameters $\left(\AA^{2}\right)$

\begin{tabular}{lllll}
\hline & $x$ & $y$ & $z$ & $U_{\mathrm{iso}} * / U_{\mathrm{eq}}$ \\
\hline $\mathrm{Br} 1$ & $0.70209(6)$ & $0.44619(3)$ & $0.34815(3)$ & $0.01868(11)$ \\
$\mathrm{Br} 2$ & $0.20145(6)$ & $0.33924(4)$ & $0.06638(3)$ & $0.01621(11)$ \\
$\mathrm{N} 1$ & $0.0313(5)$ & $-0.0658(3)$ & $0.4728(3)$ & $0.0132(5)$ \\
$\mathrm{C} 1$ & $0.4352(5)$ & $0.1125(3)$ & $0.2374(3)$ & $0.0112(5)$ \\
$\mathrm{C} 2$ & $0.5243(6)$ & $-0.0295(4)$ & $0.1812(3)$ & $0.0120(5)$ \\
$\mathrm{H} 2$ & 0.638710 & -0.023851 & 0.116479 & $0.014^{*}$ \\
$\mathrm{C} 3$ & $0.4455(6)$ & $-0.1808(4)$ & $0.2198(3)$ & $0.0139(5)$ \\
$\mathrm{H} 3$ & 0.505053 & -0.277981 & 0.181129 & $0.017^{*}$ \\
$\mathrm{C} 4$ & $0.2802(6)$ & $-0.1874(3)$ & $0.3148(3)$ & $0.0134(5)$ \\
$\mathrm{H} 4$ & 0.225421 & -0.289857 & 0.340843 & $0.016^{*}$ \\
$\mathrm{C} 5$ & $0.1935(5)$ & $-0.0453(3)$ & $0.3726(3)$ & $0.0112(5)$ \\
$\mathrm{C} 6$ & $0.2684(6)$ & $0.1049(3)$ & $0.3332(3)$ & $0.0121(5)$ \\
$\mathrm{H} 6$ & 0.206496 & 0.201498 & 0.371228 & $0.015^{*}$ \\
$\mathrm{C} 7$ & $0.5238(6)$ & $0.2695(4)$ & $0.1914(3)$ & $0.0128(5)$ \\
$\mathrm{H} 7$ & 0.667019 & 0.248602 & 0.136699 & $0.015^{*}$
\end{tabular}

Atomic displacement parameters $\left(\hat{A}^{2}\right)$

\begin{tabular}{lllllll}
\hline & $U^{11}$ & $U^{22}$ & $U^{33}$ & $U^{12}$ & $U^{13}$ & $U^{23}$ \\
\hline Br1 & $0.02306(17)$ & $0.00910(16)$ & $0.01960(17)$ & $-0.00228(11)$ & $0.00056(11)$ & $0.00057(11)$ \\
Br2 & $0.01474(16)$ & $0.01765(18)$ & $0.01783(17)$ & $0.00473(11)$ & $0.00286(10)$ & $0.00875(11)$ \\
N1 & $0.0128(10)$ & $0.0114(11)$ & $0.0144(11)$ & $0.0008(9)$ & $0.0016(8)$ & $0.0026(9)$ \\
C1 & $0.0096(11)$ & $0.0097(12)$ & $0.0123(12)$ & $0.0010(9)$ & $-0.0007(8)$ & $0.0021(9)$ \\
C2 & $0.0128(11)$ & $0.0116(13)$ & $0.0098(11)$ & $0.0021(10)$ & $0.0000(9)$ & $0.0009(10)$ \\
C3 & $0.0187(13)$ & $0.0075(12)$ & $0.0140(12)$ & $0.0035(10)$ & $0.0019(10)$ & $-0.0004(10)$ \\
C4 & $0.0165(12)$ & $0.0070(12)$ & $0.0146(12)$ & $0.0006(10)$ & $0.0010(9)$ & $0.0011(10)$ \\
C5 & $0.0099(11)$ & $0.0106(13)$ & $0.0117(11)$ & $0.0002(9)$ & $0.0005(8)$ & $0.0024(9)$ \\
C6 & $0.0126(11)$ & $0.0093(12)$ & $0.0136(12)$ & $0.0019(9)$ & $0.0016(9)$ & $0.0024(10)$ \\
C7 & $0.0114(11)$ & $0.0102(12)$ & $0.0150(12)$ & $0.0005(9)$ & $0.0007(9)$ & $0.0018(10)$ \\
\hline
\end{tabular}

Geometric parameters $\left(\AA,{ }^{\circ}\right)$

\begin{tabular}{llll}
\hline $\mathrm{Br} 1-\mathrm{C} 7$ & $1.938(3)$ & $\mathrm{C} 2-\mathrm{H} 2$ & 0.9500 \\
$\mathrm{Br} 2-\mathrm{C} 7$ & $1.965(3)$ & $\mathrm{C} 3-\mathrm{C} 4$ & $1.384(4)$ \\
$\mathrm{N} 1-\mathrm{N} 1{ }^{\mathrm{i}}$ & $1.253(5)$ & $\mathrm{C} 3-\mathrm{H} 3$ & 0.9500 \\
$\mathrm{~N} 1-\mathrm{C} 5$ & $1.429(4)$ & $\mathrm{C} 4-\mathrm{C} 5$ & $1.393(4)$ \\
$\mathrm{C} 1-\mathrm{C} 2$ & $1.393(4)$ & $\mathrm{C} 4-\mathrm{H} 4$ & 0.9500 \\
$\mathrm{C} 1-\mathrm{C} 6$ & $1.397(4)$ & $\mathrm{C} 5-\mathrm{C} 6$ & $1.393(4)$ \\
$\mathrm{C} 1-\mathrm{C} 7$ & $1.491(4)$ & $\mathrm{C} 6-\mathrm{H} 6$ & 0.9500
\end{tabular}




$\begin{array}{llll}\mathrm{C} 2-\mathrm{C} 3 & 1.402(4) & \mathrm{C} 7-\mathrm{H} 7 & 1.0000 \\ \mathrm{~N} 1-\mathrm{N} 1-\mathrm{C} 5 & 113.9(3) & \mathrm{C} 4-\mathrm{C} 5-\mathrm{C} 6 & 120.1(3) \\ \mathrm{C} 2-\mathrm{C} 1-\mathrm{C} 6 & 120.1(3) & \mathrm{C} 4-\mathrm{C} 5-\mathrm{N} 1 & 115.8(2) \\ \mathrm{C} 2-\mathrm{C} 1-\mathrm{C} 7 & 117.7(2) & \mathrm{C} 6-\mathrm{C} 5-\mathrm{N} 1 & 124.1(3) \\ \mathrm{C} 6-\mathrm{C} 1-\mathrm{C} 7 & 122.2(2) & \mathrm{C} 5-\mathrm{C} 6-\mathrm{C} 1 & 119.6(3) \\ \mathrm{C} 1-\mathrm{C} 2-\mathrm{C} 3 & 120.1(3) & \mathrm{C} 5-\mathrm{C} 6-\mathrm{H} 6 & 120.2 \\ \mathrm{C} 1-\mathrm{C} 2-\mathrm{H} 2 & 119.9 & \mathrm{C} 1-\mathrm{C} 6-\mathrm{H} 6 & 112.63(19) \\ \mathrm{C} 3-\mathrm{C} 2-\mathrm{H} 2 & 119.9 & \mathrm{C} 1-\mathrm{C} 7-\mathrm{Br} 1 & 111.38(18) \\ \mathrm{C} 4-\mathrm{C} 3-\mathrm{C} 2 & 119.4(3) & \mathrm{C} 1-\mathrm{C} 7-\mathrm{Br} 2 & 109.85(14) \\ \mathrm{C} 4-\mathrm{C} 3-\mathrm{H} 3 & 120.3 & \mathrm{Br} 1-\mathrm{C} 7-\mathrm{Br} 2 & 107.6 \\ \mathrm{C} 2-\mathrm{C} 3-\mathrm{H} 3 & 120.3 & \mathrm{C} 1-\mathrm{C} 7-\mathrm{H} 7 & 107.6 \\ \mathrm{C} 3-\mathrm{C} 4-\mathrm{C} 5 & 120.6(3) & \mathrm{B} 1-\mathrm{C} 7-\mathrm{H} 7 & \\ \mathrm{C} 3-\mathrm{C} 4-\mathrm{H} 4 & 119.7 & \mathrm{Br} 2-\mathrm{C} 7-\mathrm{H} 7 & -1.2(4) \\ \mathrm{C} 5-\mathrm{C} 4-\mathrm{H} 4 & 119.7 & & 178.0(2) \\ \mathrm{C} 6-\mathrm{C} 1-\mathrm{C} 2-\mathrm{C} 3 & & \mathrm{C} 4-\mathrm{C} 5-\mathrm{C} 6-\mathrm{C} 1 & 0.4(4) \\ \mathrm{C} 7-\mathrm{C} 1-\mathrm{C} 2-\mathrm{C} 3 & 0.4(4) & \mathrm{N} 1-\mathrm{C} 5-\mathrm{C} 6-\mathrm{C} 1 & -179.7(2) \\ \mathrm{C} 1-\mathrm{C} 2-\mathrm{C} 3-\mathrm{C} 4 & -179.5(2) & \mathrm{C} 2-\mathrm{C} 1-\mathrm{C} 6-\mathrm{C} 5 & -128.1(2) \\ \mathrm{C} 2-\mathrm{C} 3-\mathrm{C} 4-\mathrm{C} 5 & -0.4(4) & \mathrm{C} 7-\mathrm{C} 1-\mathrm{C} 6-\mathrm{C} 5 & 52.1(3) \\ \mathrm{C} 3-\mathrm{C} 4-\mathrm{C} 5-\mathrm{C} 6 & -0.4(4) & \mathrm{C} 2-\mathrm{C} 1-\mathrm{C} 7-\mathrm{Br} 1 & 108.0(2) \\ \mathrm{C} 3-\mathrm{C} 4-\mathrm{C} 5-\mathrm{N} 1 & 1.2(4) & \mathrm{C} 6-\mathrm{C} 1-\mathrm{C} 7-\mathrm{Br} 1 & -71.9(3) \\ \mathrm{N} 1-\mathrm{N} 1-\mathrm{C} 5-\mathrm{C} 4 & -178.1(3) & \mathrm{C} 2-\mathrm{C} 1-\mathrm{C} 7-\mathrm{Br} 2 & \\ \mathrm{~N} 1-\mathrm{N} 1-\mathrm{C} 5-\mathrm{C} 6 & 176.8(3) & -\mathrm{C} 1-\mathrm{C} 7-\mathrm{Br} 2 & \end{array}$

Symmetry code: (i) $-x,-y,-z+1$.

(E)-[3-(Dibromomethyl) phenyl] [3-(tribromomethyl) phenyl]diazene (9)

Crystal data

$\mathrm{C}_{14} \mathrm{H}_{9} \mathrm{Br}_{5} \mathrm{~N}_{2}$

$M_{r}=604.78$

Triclinic, $P \overline{1}$

$a=7.0161(11) \AA$

$b=8.5634(13) \AA$

$c=14.897(2) \AA$

$\alpha=103.257(2)^{\circ}$

$\beta=102.974(2)^{\circ}$

$\gamma=91.703(2)^{\circ}$

$V=845.8(2) \AA^{3}$

$Z=2$

\section{Data collection}

Bruker SMART 1000 diffractometer

Radiation source: sealed tube $\omega$ scans

Absorption correction: multi-scan (TWINABS; Sheldrick, 2012)

$T_{\min }=0.014, T_{\max }=0.052$

15148 measured reflections
$F(000)=564$

$D_{\mathrm{x}}=2.375 \mathrm{Mg} \mathrm{m}^{-3}$

Melting point: $142-143 \mathrm{C} \mathrm{K}$

Mo $K \alpha$ radiation, $\lambda=0.71073 \AA$

Cell parameters from 1139 reflections

$\theta=2.5-31.1^{\circ}$

$\mu=11.87 \mathrm{~mm}^{-1}$

$T=100 \mathrm{~K}$

Block, orange

$0.45 \times 0.43 \times 0.21 \mathrm{~mm}$

8987 independent reflections

6827 reflections with $I>2 \sigma(I)$

$R_{\text {int }}=0.066$

$\theta_{\text {max }}=31.3^{\circ}, \theta_{\min }=1.5^{\circ}$

$h=-10 \rightarrow 9$

$k=-12 \rightarrow 12$

$l=0 \rightarrow 21$ 


\section{Refinement}

Refinement on $F^{2}$

Least-squares matrix: full

$R\left[F^{2}>2 \sigma\left(F^{2}\right)\right]=0.051$

$w R\left(F^{2}\right)=0.137$

$S=0.99$

8987 reflections

213 parameters

58 restraints

Primary atom site location: structure-invariant direct methods
Secondary atom site location: difference Fourier map

Hydrogen site location: inferred from neighbouring sites

$\mathrm{H}$-atom parameters constrained

$w=1 /\left[\sigma^{2}\left(F_{\mathrm{o}}^{2}\right)+(0.0797 P)^{2}\right]$

where $P=\left(F_{\mathrm{o}}{ }^{2}+2 F_{\mathrm{c}}{ }^{2}\right) / 3$

$(\Delta / \sigma)_{\max }=0.001$

$\Delta \rho_{\max }=1.81 \mathrm{e} \AA^{-3}$

$\Delta \rho_{\min }=-1.56$ e $\AA^{-3}$

\section{Special details}

Geometry. All e.s.d.'s (except the e.s.d. in the dihedral angle between two 1.s. planes) are estimated using the full covariance matrix. The cell e.s.d.'s are taken into account individually in the estimation of e.s.d.'s in distances, angles and torsion angles; correlations between e.s.d.'s in cell parameters are only used when they are defined by crystal symmetry. An approximate (isotropic) treatment of cell e.s.d.'s is used for estimating e.s.d.'s involving l.s. planes.

Refinement. Refined as a 2-component twin. The structure was solved using direct methods with only the nonoverlapping reflections of component 1 . The structure was refined using the hklf 5 routine with all reflections of both components (including the overlapping ones), resulting in a BASF value of 0.481 (1).

Minor but clearly resolved disorder was observed for the dibromomethyl group. The major and minor moieties were restrained to have similar geometries (SAME restraint of SHELXL, e.s.d. 0.02 Angstrom). The carbon atom C10 was included in the disorder modeling and 1,2 and 1,3 $\mathrm{C}-\mathrm{C}$ distances involving the major and minor components of $\mathrm{C} 10$ were restrained to be similar (SADI restraint of SHELXL, e.s.d. 0.02 Angstrom). $U^{i j}$ components of ADPs for disordered atoms closer to each other than 2.0 Angstrom were restrained to be similar. Subject to these conditions the occupancy ratio refined to 0.9601 (19) to 0.0399 (19).

Fractional atomic coordinates and isotropic or equivalent isotropic displacement parameters $\left(\AA^{2}\right)$

\begin{tabular}{|c|c|c|c|c|c|}
\hline & $x$ & $y$ & $z$ & $U_{\text {iso }} * / U_{\text {eq }}$ & Occ. $(<1)$ \\
\hline Br1 & $0.90836(8)$ & $1.08792(7)$ & $0.36771(5)$ & $0.02429(15)$ & \\
\hline $\mathrm{Br} 2$ & $0.46223(8)$ & $1.07967(7)$ & $0.37101(5)$ & $0.02458(15)$ & \\
\hline N1 & $0.7664(6)$ & $0.6292(6)$ & $0.5351(3)$ & $0.0191(9)$ & \\
\hline N2 & $0.7756(6)$ & $0.4901(6)$ & $0.5496(3)$ & $0.0206(9)$ & \\
\hline $\mathrm{C} 1$ & $0.7187(7)$ & $0.6301(7)$ & $0.4368(4)$ & $0.0181(10)$ & \\
\hline C3 & $0.6536(7)$ & $0.9644(6)$ & $0.3090(4)$ & 0.0177 (10) & \\
\hline $\mathrm{C} 4$ & $0.6279(8)$ & $0.6584(7)$ & $0.2506(4)$ & $0.0203(10)$ & \\
\hline $\mathrm{H} 4$ & 0.595699 & 0.667201 & 0.186613 & $0.024 *$ & \\
\hline $\mathrm{C} 5$ & $0.7064(7)$ & $0.7811(7)$ & $0.4171(4)$ & $0.0179(10)$ & \\
\hline H5 & 0.729007 & 0.874865 & 0.467909 & $0.021 *$ & \\
\hline C6 & $0.6409(8)$ & $0.5070(7)$ & $0.2697(4)$ & $0.0238(11)$ & \\
\hline H6 & 0.619070 & 0.413565 & 0.218693 & $0.029 *$ & \\
\hline $\mathrm{C} 7$ & $0.8868(8)$ & $0.3130(8)$ & $0.7556(4)$ & $0.0258(12)$ & \\
\hline $\mathrm{H} 7$ & 0.901178 & 0.208546 & 0.766690 & $0.031 *$ & \\
\hline $\mathrm{C} 8$ & $0.9118(8)$ & $0.4452(7)$ & $0.8309(4)$ & $0.0251(12)$ & \\
\hline $\mathrm{H} 8$ & 0.944967 & 0.431907 & 0.893937 & $0.030 *$ & \\
\hline C9 & $0.6853(8)$ & $0.4911(7)$ & $0.3621(4)$ & $0.0212(10)$ & \\
\hline H9 & 0.693124 & 0.387486 & 0.374978 & $0.025^{*}$ & \\
\hline $\mathrm{C} 11$ & $0.8212(7)$ & $0.4838(7)$ & $0.6464(4)$ & $0.0191(10)$ & \\
\hline $\mathrm{C} 12$ & $0.8889(8)$ & $0.5986(7)$ & $0.8152(4)$ & $0.0228(11)$ & \\
\hline $\mathrm{C} 14$ & $0.8450(7)$ & $0.6200(7)$ & $0.7228(4)$ & $0.0205(10)$ & \\
\hline
\end{tabular}




\begin{tabular}{llllll} 
H14 & 0.831452 & 0.724552 & 0.711806 & $0.025^{*}$ & \\
C15 & $0.8403(8)$ & $0.3321(7)$ & $0.6629(4)$ & $0.0217(11)$ & \\
H15 & 0.821753 & 0.240510 & 0.610947 & $0.026^{*}$ & \\
C16 & $0.6612(7)$ & $0.7963(7)$ & $0.3236(4)$ & $0.0186(10)$ & \\
Br3 & $0.58568(11)$ & $0.97768(9)$ & $0.17782(4)$ & $0.03647(18)$ & \\
C10 & $0.9060(9)$ & $0.7456(8)$ & $0.8944(4)$ & $0.0281(13)$ & $0.9601(19)$ \\
H10 & 0.878219 & 0.840293 & 0.866313 & $0.034^{*}$ & $0.9601(19)$ \\
Br4 & $0.71615(10)$ & $0.72607(10)$ & $0.97006(5)$ & $0.0349(2)$ & $0.9601(19)$ \\
Br5 & $1.16852(11)$ & $0.78735(12)$ & $0.98005(6)$ & $0.0371(2)$ & $0.9601(19)$ \\
C10B & $0.942(6)$ & $0.735(2)$ & $0.9006(16)$ & $0.034(7)$ & $0.0399(19)$ \\
H10B & 0.851659 & 0.724703 & 0.942383 & $0.041^{*}$ & $0.0399(19)$ \\
Br4B & $0.910(3)$ & $0.930(2)$ & $0.8670(14)$ & $0.049(5)$ & $0.0399(19)$ \\
Br5B & $1.209(3)$ & $0.711(3)$ & $0.9683(15)$ & $0.0371(2)$ & $0.0399(19)$ \\
\hline
\end{tabular}

Atomic displacement parameters $\left(\AA^{2}\right)$

\begin{tabular}{lllllll}
\hline & $U^{11}$ & $U^{22}$ & $U^{33}$ & $U^{12}$ & $U^{13}$ & $U^{23}$ \\
\hline $\mathrm{Br} 1$ & $0.0214(3)$ & $0.0195(3)$ & $0.0315(3)$ & $0.00001(18)$ & $0.0047(2)$ & $0.0070(2)$ \\
$\mathrm{Br} 2$ & $0.0248(3)$ & $0.0212(3)$ & $0.0314(3)$ & $0.0066(2)$ & $0.0109(2)$ & $0.0091(2)$ \\
$\mathrm{N} 1$ & $0.020(2)$ & $0.020(2)$ & $0.017(2)$ & $0.0008(16)$ & $0.0021(16)$ & $0.0049(18)$ \\
$\mathrm{N} 2$ & $0.024(2)$ & $0.020(2)$ & $0.019(2)$ & $0.0013(17)$ & $0.0053(17)$ & $0.0067(19)$ \\
$\mathrm{C} 1$ & $0.018(2)$ & $0.017(3)$ & $0.018(2)$ & $-0.0003(17)$ & $0.0016(18)$ & $0.004(2)$ \\
$\mathrm{C} 3$ & $0.025(2)$ & $0.017(3)$ & $0.009(2)$ & $0.0005(18)$ & $0.0024(18)$ & $-0.0006(19)$ \\
$\mathrm{C} 4$ & $0.024(2)$ & $0.021(3)$ & $0.014(2)$ & $0.0005(19)$ & $0.0027(19)$ & $0.000(2)$ \\
$\mathrm{C} 5$ & $0.023(2)$ & $0.016(3)$ & $0.012(2)$ & $0.0020(18)$ & $0.0036(18)$ & $-0.0009(19)$ \\
$\mathrm{C} 6$ & $0.025(3)$ & $0.021(3)$ & $0.021(3)$ & $0.000(2)$ & $0.002(2)$ & $-0.001(2)$ \\
$\mathrm{C} 7$ & $0.028(3)$ & $0.024(3)$ & $0.031(3)$ & $0.005(2)$ & $0.009(2)$ & $0.015(2)$ \\
$\mathrm{C} 8$ & $0.027(3)$ & $0.025(3)$ & $0.026(3)$ & $0.004(2)$ & $0.005(2)$ & $0.012(2)$ \\
$\mathrm{C} 9$ & $0.024(2)$ & $0.014(3)$ & $0.023(3)$ & $-0.0007(19)$ & $0.004(2)$ & $0.003(2)$ \\
$\mathrm{C} 11$ & $0.019(2)$ & $0.021(3)$ & $0.018(3)$ & $0.0020(18)$ & $0.0026(19)$ & $0.007(2)$ \\
$\mathrm{C} 12$ & $0.023(3)$ & $0.025(3)$ & $0.021(3)$ & $0.001(2)$ & $0.005(2)$ & $0.007(2)$ \\
$\mathrm{C} 14$ & $0.022(2)$ & $0.018(3)$ & $0.023(3)$ & $0.0022(19)$ & $0.005(2)$ & $0.008(2)$ \\
$\mathrm{C} 15$ & $0.025(2)$ & $0.017(3)$ & $0.025(3)$ & $0.0035(19)$ & $0.006(2)$ & $0.006(2)$ \\
$\mathrm{C} 16$ & $0.019(2)$ & $0.021(3)$ & $0.017(3)$ & $0.0016(18)$ & $0.0063(19)$ & $0.006(2)$ \\
$\mathrm{Br} 3$ & $0.0642(4)$ & $0.0289(4)$ & $0.0136(3)$ & $0.0024(3)$ & $0.0029(3)$ & $0.0060(2)$ \\
$\mathrm{C} 10$ & $0.035(3)$ & $0.030(3)$ & $0.017(3)$ & $0.001(2)$ & $0.000(2)$ & $0.007(3)$ \\
$\mathrm{Br} 4$ & $0.0415(4)$ & $0.0424(4)$ & $0.0201(3)$ & $0.0067(3)$ & $0.0107(3)$ & $0.0022(3)$ \\
$\mathrm{Br} 5$ & $0.0384(4)$ & $0.0395(5)$ & $0.0274(4)$ & $-0.0099(3)$ & $-0.0045(3)$ & $0.0095(3)$ \\
$\mathrm{C} 10 \mathrm{~B}$ & $0.040(11)$ & $0.035(11)$ & $0.022(10)$ & $-0.002(10)$ & $-0.001(10)$ & $0.007(10)$ \\
$\mathrm{Br} 4 \mathrm{~B}$ & $0.063(10)$ & $0.045(10)$ & $0.027(9)$ & $0.009(8)$ & $-0.004(7)$ & $0.000(8)$ \\
$\mathrm{Br} 5 \mathrm{~B}$ & $0.0384(4)$ & $0.0395(5)$ & $0.0274(4)$ & $-0.0099(3)$ & $-0.0045(3)$ & $0.0095(3)$ \\
& & & & & & \\
\hline
\end{tabular}

Geometric parameters $\left(A,{ }^{\circ}\right)$

\begin{tabular}{llll}
\hline $\mathrm{Br} 1-\mathrm{C} 3$ & $1.960(5)$ & $\mathrm{C} 7-\mathrm{H} 7$ & 0.9500 \\
$\mathrm{Br} 2-\mathrm{C} 3$ & $1.962(5)$ & $\mathrm{C} 8-\mathrm{C} 12$ & $1.394(8)$ \\
$\mathrm{N} 1-\mathrm{N} 2$ & $1.259(7)$ & $\mathrm{C} 8-\mathrm{H} 8$ & 0.9500 \\
$\mathrm{~N} 1-\mathrm{C} 1$ & $1.428(7)$ & $\mathrm{C} 9-\mathrm{H} 9$ & 0.9500
\end{tabular}




\begin{tabular}{|c|c|c|c|}
\hline $\mathrm{N} 2-\mathrm{C} 11$ & $1.420(7)$ & $\mathrm{C} 11-\mathrm{C} 15$ & $1.381(8)$ \\
\hline $\mathrm{C} 1-\mathrm{C} 5$ & $1.391(8)$ & $\mathrm{C} 11-\mathrm{C} 14$ & $1.407(8)$ \\
\hline $\mathrm{C} 1-\mathrm{C} 9$ & $1.403(8)$ & $\mathrm{C} 12-\mathrm{C} 14$ & $1.398(8)$ \\
\hline $\mathrm{C} 3-\mathrm{C} 16$ & $1.505(8)$ & $\mathrm{C} 12-\mathrm{C} 10 \mathrm{~B}$ & $1.484(19)$ \\
\hline $\mathrm{C} 3-\mathrm{Br} 3$ & $1.935(5)$ & $\mathrm{C} 12-\mathrm{C} 10$ & $1.495(9)$ \\
\hline $\mathrm{C} 4-\mathrm{C} 16$ & $1.383(7)$ & $\mathrm{C} 14-\mathrm{H} 14$ & 0.9500 \\
\hline $\mathrm{C} 4-\mathrm{C} 6$ & $1.392(8)$ & $\mathrm{C} 15-\mathrm{H} 15$ & 0.9500 \\
\hline $\mathrm{C} 4-\mathrm{H} 4$ & 0.9500 & $\mathrm{C} 10-\mathrm{Br} 4$ & $1.954(7)$ \\
\hline $\mathrm{C} 5-\mathrm{C} 16$ & $1.394(7)$ & $\mathrm{C} 10-\mathrm{Br} 5$ & $1.960(6)$ \\
\hline $\mathrm{C} 5-\mathrm{H} 5$ & 0.9500 & $\mathrm{C} 10-\mathrm{H} 10$ & 1.0000 \\
\hline $\mathrm{C} 6-\mathrm{C} 9$ & $1.381(8)$ & $\mathrm{C} 10 \mathrm{~B}-\mathrm{Br} 4 \mathrm{~B}$ & $1.86(2)$ \\
\hline $\mathrm{C} 6-\mathrm{H} 6$ & 0.9500 & $\mathrm{C} 10 \mathrm{~B}-\mathrm{Br} 5 \mathrm{~B}$ & $1.95(3)$ \\
\hline $\mathrm{C} 7-\mathrm{C} 8$ & $1.374(9)$ & $\mathrm{C} 10 \mathrm{~B}-\mathrm{H} 10 \mathrm{~B}$ & 1.0000 \\
\hline $\mathrm{C} 7-\mathrm{C} 15$ & $1.394(8)$ & & \\
\hline $\mathrm{N} 2-\mathrm{N} 1-\mathrm{C} 1$ & $113.7(5)$ & $\mathrm{C} 15-\mathrm{C} 11-\mathrm{C} 14$ & $120.3(5)$ \\
\hline $\mathrm{N} 1-\mathrm{N} 2-\mathrm{C} 11$ & $115.5(5)$ & $\mathrm{C} 15-\mathrm{C} 11-\mathrm{N} 2$ & $115.8(5)$ \\
\hline $\mathrm{C} 5-\mathrm{C} 1-\mathrm{C} 9$ & $119.9(5)$ & $\mathrm{C} 14-\mathrm{C} 11-\mathrm{N} 2$ & $123.9(5)$ \\
\hline $\mathrm{C} 5-\mathrm{C} 1-\mathrm{N} 1$ & $115.8(5)$ & $\mathrm{C} 8-\mathrm{C} 12-\mathrm{C} 14$ & $120.3(6)$ \\
\hline $\mathrm{C} 9-\mathrm{C} 1-\mathrm{N} 1$ & $124.2(5)$ & $\mathrm{C} 8-\mathrm{C} 12-\mathrm{C} 10 \mathrm{~B}$ & $116.3(10)$ \\
\hline $\mathrm{C} 16-\mathrm{C} 3-\mathrm{Br} 3$ & $115.2(4)$ & $\mathrm{C} 14-\mathrm{C} 12-\mathrm{C} 10 \mathrm{~B}$ & $122.8(11)$ \\
\hline $\mathrm{C} 16-\mathrm{C} 3-\mathrm{Br} 1$ & $110.3(3)$ & $\mathrm{C} 8-\mathrm{C} 12-\mathrm{C} 10$ & $122.6(6)$ \\
\hline $\mathrm{Br} 3-\mathrm{C} 3-\mathrm{Br} 1$ & $106.9(3)$ & $\mathrm{C} 14-\mathrm{C} 12-\mathrm{C} 10$ & $117.1(6)$ \\
\hline $\mathrm{C} 16-\mathrm{C} 3-\mathrm{Br} 2$ & $110.6(3)$ & $\mathrm{C} 12-\mathrm{C} 14-\mathrm{C} 11$ & $118.7(5)$ \\
\hline $\mathrm{Br} 3-\mathrm{C} 3-\mathrm{Br} 2$ & $107.0(2)$ & $\mathrm{C} 12-\mathrm{C} 14-\mathrm{H} 14$ & 120.7 \\
\hline $\mathrm{Br} 1-\mathrm{C} 3-\mathrm{Br} 2$ & $106.4(2)$ & $\mathrm{C} 11-\mathrm{C} 14-\mathrm{H} 14$ & 120.7 \\
\hline $\mathrm{C} 16-\mathrm{C} 4-\mathrm{C} 6$ & $120.8(5)$ & $\mathrm{C} 11-\mathrm{C} 15-\mathrm{C} 7$ & $120.3(6)$ \\
\hline $\mathrm{C} 16-\mathrm{C} 4-\mathrm{H} 4$ & 119.6 & $\mathrm{C} 11-\mathrm{C} 15-\mathrm{H} 15$ & 119.9 \\
\hline $\mathrm{C} 6-\mathrm{C} 4-\mathrm{H} 4$ & 119.6 & $\mathrm{C} 7-\mathrm{C} 15-\mathrm{H} 15$ & 119.9 \\
\hline $\mathrm{C} 1-\mathrm{C} 5-\mathrm{C} 16$ & $120.7(5)$ & $\mathrm{C} 4-\mathrm{C} 16-\mathrm{C} 5$ & $118.8(5)$ \\
\hline $\mathrm{C} 1-\mathrm{C} 5-\mathrm{H} 5$ & 119.6 & $\mathrm{C} 4-\mathrm{C} 16-\mathrm{C} 3$ & $124.0(5)$ \\
\hline $\mathrm{C} 16-\mathrm{C} 5-\mathrm{H} 5$ & 119.6 & $\mathrm{C} 5-\mathrm{C} 16-\mathrm{C} 3$ & $117.1(5)$ \\
\hline $\mathrm{C} 9-\mathrm{C} 6-\mathrm{C} 4$ & $120.7(5)$ & $\mathrm{C} 12-\mathrm{C} 10-\mathrm{Br} 4$ & $111.1(4)$ \\
\hline $\mathrm{C} 9-\mathrm{C} 6-\mathrm{H} 6$ & 119.7 & $\mathrm{C} 12-\mathrm{C} 10-\mathrm{Br} 5$ & $112.4(4)$ \\
\hline $\mathrm{C} 4-\mathrm{C} 6-\mathrm{H} 6$ & 119.7 & $\mathrm{Br} 4-\mathrm{C} 10-\mathrm{Br} 5$ & $107.9(3)$ \\
\hline $\mathrm{C} 8-\mathrm{C} 7-\mathrm{C} 15$ & $119.9(6)$ & $\mathrm{C} 12-\mathrm{C} 10-\mathrm{H} 10$ & 108.4 \\
\hline $\mathrm{C} 8-\mathrm{C} 7-\mathrm{H} 7$ & 120.0 & $\mathrm{Br} 4-\mathrm{C} 10-\mathrm{H} 10$ & 108.4 \\
\hline $\mathrm{C} 15-\mathrm{C} 7-\mathrm{H} 7$ & 120.0 & $\mathrm{Br} 5-\mathrm{C} 10-\mathrm{H} 10$ & 108.4 \\
\hline $\mathrm{C} 7-\mathrm{C} 8-\mathrm{C} 12$ & $120.4(6)$ & $\mathrm{C} 12-\mathrm{C} 10 \mathrm{~B}-\mathrm{Br} 4 \mathrm{~B}$ & $110.8(14)$ \\
\hline $\mathrm{C} 7-\mathrm{C} 8-\mathrm{H} 8$ & 119.8 & $\mathrm{C} 12-\mathrm{C} 10 \mathrm{~B}-\mathrm{Br} 5 \mathrm{~B}$ & $107.0(18)$ \\
\hline $\mathrm{C} 12-\mathrm{C} 8-\mathrm{H} 8$ & 119.8 & $\mathrm{Br} 4 \mathrm{~B}-\mathrm{C} 10 \mathrm{~B}-\mathrm{Br} 5 \mathrm{~B}$ & $115(2)$ \\
\hline $\mathrm{C} 6-\mathrm{C} 9-\mathrm{C} 1$ & $119.1(5)$ & $\mathrm{C} 12-\mathrm{C} 10 \mathrm{~B}-\mathrm{H} 10 \mathrm{~B}$ & 108.1 \\
\hline $\mathrm{C} 6-\mathrm{C} 9-\mathrm{H} 9$ & 120.5 & $\mathrm{Br} 4 \mathrm{~B}-\mathrm{C} 10 \mathrm{~B}-\mathrm{H} 10 \mathrm{~B}$ & 108.1 \\
\hline $\mathrm{C} 1-\mathrm{C} 9-\mathrm{H} 9$ & 120.5 & $\mathrm{Br} 5 \mathrm{~B}-\mathrm{C} 10 \mathrm{~B}-\mathrm{H} 10 \mathrm{~B}$ & 108.1 \\
\hline $\mathrm{C} 1-\mathrm{N} 1-\mathrm{N} 2-\mathrm{C} 11$ & $-179.5(4)$ & $\mathrm{N} 2-\mathrm{C} 11-\mathrm{C} 15-\mathrm{C} 7$ & $179.4(5)$ \\
\hline $\mathrm{N} 2-\mathrm{N} 1-\mathrm{C} 1-\mathrm{C} 5$ & $179.9(4)$ & $\mathrm{C} 8-\mathrm{C} 7-\mathrm{C} 15-\mathrm{C} 11$ & $0.6(8)$ \\
\hline $\mathrm{N} 2-\mathrm{N} 1-\mathrm{C} 1-\mathrm{C} 9$ & $-0.3(7)$ & $\mathrm{C} 6-\mathrm{C} 4-\mathrm{C} 16-\mathrm{C} 5$ & $-0.6(8)$ \\
\hline
\end{tabular}




$\begin{array}{llll}\mathrm{C} 9-\mathrm{C} 1-\mathrm{C} 5-\mathrm{C} 16 & 0.0(8) & \mathrm{C} 6-\mathrm{C} 4-\mathrm{C} 16-\mathrm{C} 3 & 178.8(5) \\ \mathrm{N} 1-\mathrm{C} 1-\mathrm{C} 5-\mathrm{C} 16 & 179.8(4) & \mathrm{C} 1-\mathrm{C} 5-\mathrm{C} 16-\mathrm{C} 4 & 0.3(8) \\ \mathrm{C} 16-\mathrm{C} 4-\mathrm{C} 6-\mathrm{C} 9 & 0.7(8) & \mathrm{C} 1-\mathrm{C} 5-\mathrm{C} 16-\mathrm{C} 3 & -179.2(4) \\ \mathrm{C} 15-\mathrm{C} 7-\mathrm{C} 8-\mathrm{C} 12 & 0.7(8) & \mathrm{B} 3-\mathrm{C} 3-\mathrm{C} 16-\mathrm{C} 4 & 1.6(7) \\ \mathrm{C} 4-\mathrm{C} 6-\mathrm{C} 9-\mathrm{C} 1 & -0.5(8) & \mathrm{Br} 1-\mathrm{C} 3-\mathrm{C} 16-\mathrm{C} 4 & -119.5(5) \\ \mathrm{C} 5-\mathrm{C} 1-\mathrm{C} 9-\mathrm{C} 6 & 0.1(8) & \mathrm{B} 2-\mathrm{C} 3-\mathrm{C} 16-\mathrm{C} 4 & 123.0(5) \\ \mathrm{N} 1-\mathrm{C} 1-\mathrm{C} 9-\mathrm{C} 6 & -179.7(5) & \mathrm{Br}-\mathrm{C} 3-\mathrm{C} 16-\mathrm{C} 5 & -179.0(4) \\ \mathrm{N} 1-\mathrm{N} 2-\mathrm{C} 11-\mathrm{C} 15 & -177.1(5) & \mathrm{Br} 1-\mathrm{C} 3-\mathrm{C} 16-\mathrm{C} 5 & 59.9(5) \\ \mathrm{N} 1-\mathrm{N} 2-\mathrm{C} 11-\mathrm{C} 14 & 3.4(7) & \mathrm{B} 2-\mathrm{C} 3-\mathrm{C} 16-\mathrm{C} 5 & -57.5(5) \\ \mathrm{C} 7-\mathrm{C} 8-\mathrm{C} 12-\mathrm{C} 14 & -1.6(8) & \mathrm{C} 8-\mathrm{C} 12-\mathrm{C} 10-\mathrm{Br} 4 & -58.4(7) \\ \mathrm{C} 7-\mathrm{C} 8-\mathrm{C} 12-\mathrm{C} 10 \mathrm{~B} & -173(2) & \mathrm{C} 14-\mathrm{C} 12-\mathrm{C} 10-\mathrm{Br} 4 & 120.5(5) \\ \mathrm{C} 7-\mathrm{C} 8-\mathrm{C} 12-\mathrm{C} 10 & 177.3(5) & \mathrm{C} 8-\mathrm{C} 12-\mathrm{C} 10-\mathrm{Br} 5 & 62.7(7) \\ \mathrm{C} 8-\mathrm{C} 12-\mathrm{C} 14-\mathrm{C} 11 & 1.1(8) & \mathrm{C} 14-\mathrm{C} 12-\mathrm{C} 10-\mathrm{Br} 5 & -118.4(5) \\ \mathrm{C} 10 \mathrm{~B}-\mathrm{C} 12-\mathrm{C} 14-\mathrm{C} 11 & 172(2) & \mathrm{C} 8-\mathrm{C} 12-\mathrm{C} 10 \mathrm{~B}-\mathrm{Br} 4 \mathrm{~B} & 178.3(15) \\ \mathrm{C} 10-\mathrm{C} 12-\mathrm{C} 14-\mathrm{C} 11 & -177.9(5) & \mathrm{C} 14-\mathrm{C} 12-\mathrm{C} 10 \mathrm{~B}-\mathrm{Br} 4 \mathrm{~B} & 7(3) \\ \mathrm{C} 15-\mathrm{C} 11-\mathrm{C} 14-\mathrm{C} 12 & 0.3(8) & \mathrm{C} 8-\mathrm{C} 12-\mathrm{C} 10 \mathrm{~B}-\mathrm{Br} 5 \mathrm{~B} & 53(3) \\ \mathrm{N} 2-\mathrm{C} 11-\mathrm{C} 14-\mathrm{C} 12 & 179.7(5) & \mathrm{C} 14-\mathrm{C} 12-\mathrm{C} 10 \mathrm{~B}-\mathrm{Br} 5 \mathrm{~B} & -118.3(12) \\ \mathrm{C} 14-\mathrm{C} 11-\mathrm{C} 15-\mathrm{C} 7 & -1.1(8) & & \\ & & & \end{array}$

